\title{
Foraminiferal response to the deposition of insolation cycle 90 sapropel in different Mediterranean areas
}

\author{
SIMONA STEFANELLI ${ }^{1} \&$ LUCILLA CAPOTONDI $^{2}$ \\ ${ }^{1}$ Geology and Geophysics Department, Via Orabona 4, 70125 Bari, Italy (e-mail: stefanelli@geo.uniba.it) \\ ${ }^{2}$ ISMAR- Marine Geology Section, CNR, Via Gobetti 101, 40129 Bologna, Italy
}

\begin{abstract}
Foraminifera were investigated across the sapropel unit corresponding to insolation cycle 90 deposited in three different oceanographic and depositional settings of the Mediterranean Sea (Alboran Sea, South Adriatic Sea and Ionian Sea). The constant presence of benthic foraminifera throughout the sapropels at $<2000 \mathrm{~m}$ water depth and their absence within the sapropel at greater depth $(>3000 \mathrm{~m})$ indicate that the severity of oxygen depletion at the time of sapropel onset increases with increasing water depth.

Planktonic and benthic foraminiferal patterns also document an interruption during sapropel deposition, which allows for the recognition of two sapropel phases. In all basins, the short interruption appears to be related to climatic deterioration, which led to the break in stratification and, hence, to the re-oxygenation of bottom waters. Since the interruption of the time-equivalent sapropel intervals has been documented previously in other Mediterranean areas, these data support the recent theory that this interruption must have been a trans-Mediterranean phenomenon and that the interruption records a short excursion out of the periods of wet climate associated with precessional minima. J. Micropalaeontol. 27(1): 45-61, May 2008.
\end{abstract}

KEYWORDS: benthic and planktonic foraminifera, sapropel, i-cycle 90, Pleistocene, Mediterranean

\section{INTRODUCTION}

In the Mediterranean Sea, numerous dark-coloured layers, termed sapropels (Cita \& Grignani, 1982; Thunell et al., 1983; Hilgen, 1991), have been found in marine and land sequences (summary in Rohling \& Hilgen, 1991 and references therein). Sapropel formation has been shown to be astronomically timecontrolled, occurring around minima in the precessional cycle (Rossignol-Strick, 1985; Hilgen, 1991). The precessional minima with which sapropels coincide were periods of wetter climate in the Mediterranean Basin (Rossignol-Strick, 1983; Rohling \& Hilgen, 1991).

The debate over the mechanisms that led to the formation of sapropels still remains unresolved. Two models have been proposed to explain the enrichment in organic carbon during their formation: the productivity model and the stagnation model. The productivity model postulates that the formation of sapropel correlates with periods of enhanced marine productivity and consequent increased flux of organic matter to the seafloor (Calvert \& Pedersen, 1992; Lourens et al., 1992; Castradori, 1993; Sancetta, 1994). In the stagnation model, anoxia is proposed as the dominant mechanism, enhancing organic matter preservation by increasing density stratification in the water column (Rossignol-Strick et al., 1982; Thunell \& Williams, 1989; Bethoux, 1993; Tang \& Stott, 1993).

It is now widely accepted that primary productivity and restricted bottom water ventilation are not mutually exclusive as mechanisms leading to sapropel formation (Cramp \& O’Sullivan, 1999; Sancetta, 1999).

Although the occurrence of same-age sapropel layers (Legs 160 and 161) extends across the entire Mediterranean (Comas et al., 1996; Emeis et al., 1996; de Kaenel et al., 1999; Murat, 1999), marked differences have been observed in organic carbon content and geochemical properties between the western and the eastern areas (Nijenhuis et al., 2001; Meyers \& Arnaboldi, 2005; Meyers \& Bernasconi, 2005). This can mean either that the western and eastern basins responded differently to the same regional/global forcing factors, or that the dominant mechanisms triggering sapropel formation were not operating to the same extent within the two basins. These hypotheses may find foundation in one of the major questions argued by Emeis et al. (2000) and are still open. They hypothesized that the 3000-year lag assumed for sapropel deposition in response to the minima in the astronomical procession index could have had implications for the processes acting in the Mediterranean Sea during the transition from non-sapropel to sapropel stage. This observation suggests that local climatic conditions during insolation maxima may have differently influenced the reduction in ventilation of the water mass and/or the increase in primary productivity in the photic layer.

In this context, it would be interesting to assess whether the oxygen content in the water masses and productivity enhancement were distributed uniformly across the Mediterranean Sea during the deposition of coeval sapropels. Foraminiferal patterns across synchronous sapropel intervals could then provide a good investigative tool. As demonstrated widely, planktonic foraminiferal associations within sapropels reflect periods of enhanced primary productivity in the water column (Rohling \& Gieskes, 1989), whilst benthic foraminiferal faunas from sapropels reflect changes in bottom-water ventilation (Cita \& Podenzani, 1980; Mullineaux \& Lohmann, 1981; Ross \& Kennett, 1983/84; Vismara-Schilling, 1984; Oggioni \& Zandini, 1987; Nolet \& Corliss, 1990; Jorissen, 1999; Schmiedl et al., 2003).

This paper discusses a micropalaeontological study across the sediments from mid-Pleistocene insolation cycle $90(955 \mathrm{Ka})$ deposited in different basins and at different water depth and 
recovered at ODP drill-holes 977A (Alboran Basin, western Mediterranean) and 964D (Ionian Sea, eastern Mediterranean). A further purpose is to compare the sapropel recorded in the marine sediments (cores) with the time-equivalent sapropel layer found in the IM/Fosso 5 Agosto land section (Stefanelli et al., 2005). The high sedimentation rate of the Montalbano Jonico section (estimated to be about $50 \mathrm{~cm} \mathrm{ka}^{-1}$ ) offers an opportunity to examine an expanded stratigraphical interval (about $6 \mathrm{~m}$ thick). A high-resolution distributional pattern of benthic and planktonic foraminifera within the sapropel interval documents an ecosystem variability related to the unstable nature of bottom-water oxygen content (Stefanelli et al., 2005). The main aim is to assess differences/similarities in the i-cycle 90 sapropel expression and, thereby, to respond to the following question: how did the differences in hydrographic regime and in depth of depositional basin affect the formation of coeval sapropel?

\section{Mediterranean circulation}

The Mediterranean Sea is a semi-enclosed basin surrounded almost entirely by continents. Therefore, hydrography and sedimentation processes are controlled by the regional climate and topography of the adjacent land masses. The Mediterranean's physical circulation is driven by a surface wind that creates a pronounced eddy circulation in the surface layer, and by thermohaline gradients that drive intermediate and deep-water circulation (Emeis et al., 1996). The circulation pattern is anti-estuarine and is characterized by four major water masses (Wust, 1961; Rohling, 1991; Bethoux et al., 1999; Lascaratos et al., 1999; Send et al., 1999; Béranger et al., 2005): Atlantic Water (AW), Levantine Intermediate Water (LIW), Eastern Mediterranean Deep Water and Western Mediterranean Deep Water. Among them, in terms of sapropel formation, LIW plays the principal role, as reported by Rohling \& Gieskes (1989) and Rohling (1991). The intermediate water mass was more rich in nutrients with respect to the overlying surface water. The nutricline is found in association with the halocline, between the surface and intermediate waters. As a consequence, at the time of sapropel formation, the shoaling of the halocline within the euphotic layer, due to a change in the circulation pattern, gave rise to the development of the deep chlorophyll maximum (DCM) below the halocline. The consequence was an increase in the downward flux of organic matter from the euphotic layer, which caused oxygen consumption at greater depth.

\section{SAMPLING AND METHODS}

The sapropel interval associated with insolation cycle 90 and MIS 25, dated at $955 \mathrm{Ka}$ (de Kaenel et al., 1999; Emeis et al., 2000) from ODP Hole 977A (Leg 161) and Hole 964D (Leg 160) was investigated (Fig. 1).

In this study the age model provided by Howell et al. (1998) and von Grafenstein et al., (1999) is adopted. The stratigraphical depth of sapropel boundaries (base and top) are those indicated by Murat (1999) and Emeis et al. (2000).

Site 977 is located in the Eastern Alboran Basin to the south of Cabo de Gata, halfway between the Spanish and Algerian coasts, at a water depth of $1984 \mathrm{~m}$. Core 18X-1 was sampled in the stratigraphical interval between 156.68 and 156.0 revised metres composite depth (rmcd) (25 samples in total). The investigated interval corresponds to the termination of MIS 26 and the beginning of MIS 25 (von Grafenstein et al., 1999). The sapropel layer does not show an evident change in colour and is documented between 156.34 and $156.24 \mathrm{rmcd}$ (Murat, 1999).

Site 964 is located in the Ionian Basin at the foot of the Calabrian Ridge on a small bathymetric high, the Pisano Plateau, at a water depth of $3666 \mathrm{~m}$. Core $4 \mathrm{H}-4$ was sampled in the interval between $34.53 \mathrm{rmcd}$ and $33.85 \mathrm{rmcd}$ ( 35 samples). The investigated stratigraphic interval is enclosed entirely in MIS 25 (Howell et al., 1998). The $12 \mathrm{~cm}$ thick sapropel (34.30$34.18 \mathrm{rmcd}$ ) exhibits sharp lower and upper boundaries. It is a composite sapropel with two dark-coloured beds. The lower dark-coloured bed is at 34.295-34. $285 \mathrm{rmcd}$ depth, the uppermost one is at 34.235-34.205 rmcd depth.

Samples were also collected at the Bremen ODP Core Repository. The targeted cores were sampled at $2 \mathrm{~cm}$ spacing on average. Samples are $2 \mathrm{~cm}$ in diameter and the sample depths refer to midpoints of samples. Sediment samples were dried, weighed and washed through a $63 \mu \mathrm{m}$ screen. Subsequently, the coarse fraction was dry sieved at $125 \mu \mathrm{m}$ and $250 \mu \mathrm{m}$. The analysis of benthic foraminifera was carried out on the split size fractions $>63 \mu \mathrm{m}$. All the benthic foraminifera were counted and identified specifically whenever possible, or at generic level. Finally, all the counts were corrected for splits and the concentration of the benthic foraminifera was calculated as number of specimens per gram of dry sediment as well as percentages of frequency.

The diversity index $H(S)$ and the dominance of the taxa $(D)$ were also determined by means of the PAST (PALeontology STatistic) Program (Hammer et al., 2001). They were performed on a raw data matrix of columns, each containing the count of individuals of different benthic taxa (per sample) down the row. The diversity index varies from 0 for associations with a single taxon, to high values for associations with many taxa, each with few individuals. Dominance varies from 0 , when all the taxa are equally present in the association, to 1 when only one taxon dominates the association.

The planktonic foraminiferal analysis examined the same samples used for benthic foraminifer's counts. The planktonic foraminiferal counts were made on splits of 250-400 specimens from the $>63 \mu \mathrm{m}$ fraction, and then their percentages of frequency were calculated. Successively, the percentage values were used for the application of a statistical method, Hierarchical Cluster Analysis (HCA), performed by means of SPSS program version 9.0, in order to demonstrate the linkage between taxa distribution and palaeoenvironmental gradients. For the analysis, those benthic and planktonic taxa with frequency values greater than $2 \%$ - as well as those of particular environmental significance - were selected.

The outcome of the HCA is a dendrogram in which foraminifera, with (palaeo)ecological similarity, are grouped into clusters. Each of these clusters can represent a distinct community from which it is possible to draw palaeoecological interpretations.

A raw data matrix, comprising $n$ number of samples (in rows) $\times n$ number of taxa (in columns), was used and the clustering was performed in R-mode. The most significant dendrograms were obtained using the Average-Linkage Within Group, Pearson correlation. 


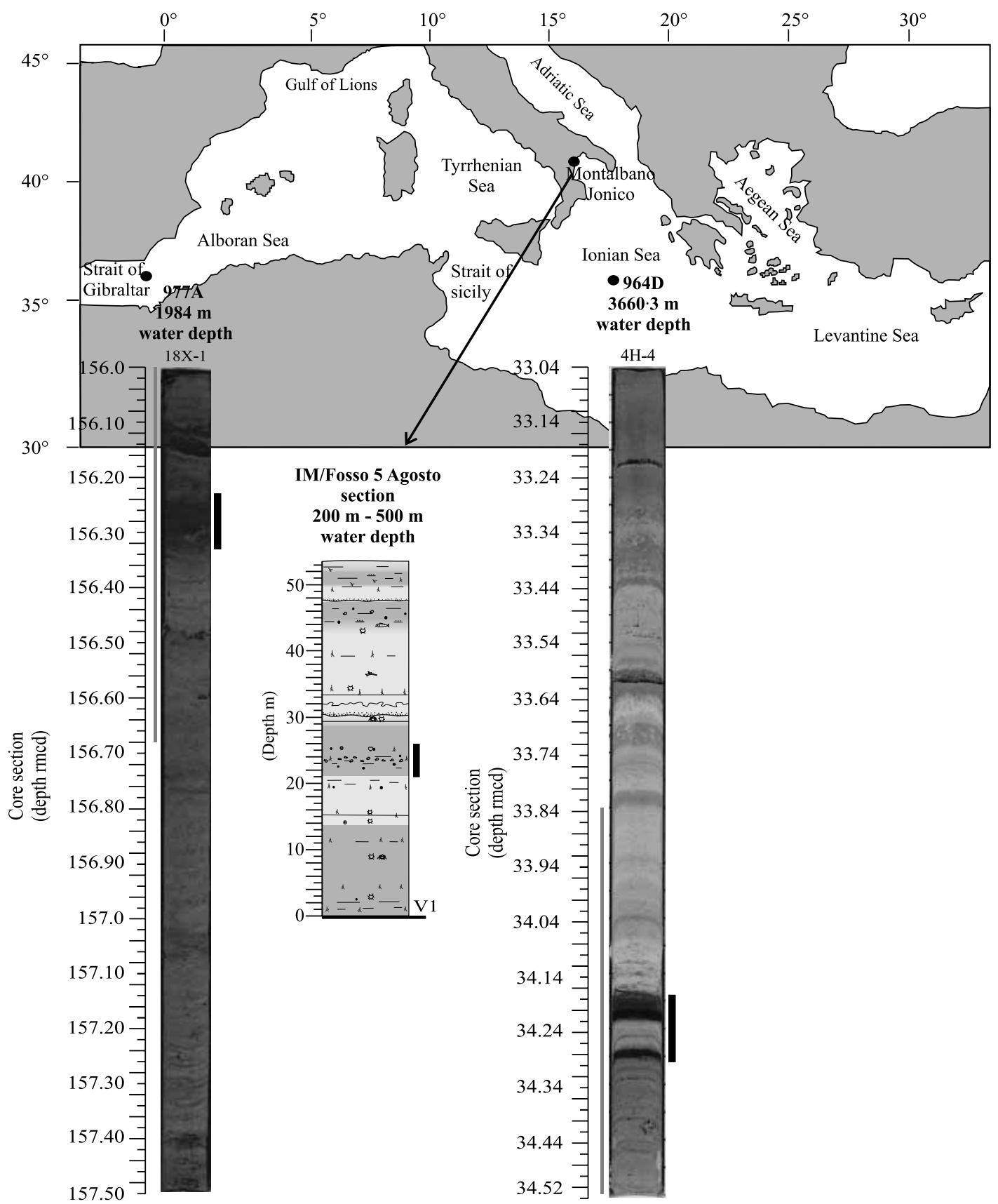

Fig. 1. Mediterranean basin with location of the investigated sites. The grey side-bars indicate the stratigraphic intervals studied for this work. The black side-bars indicate the stratigraphic interval of the sapropel layer associated with i-cycle 90 .

The last step of HCA involves performing cumulative plots (the sum of the percentages of frequency of the taxa present in each cluster) in order to observe the stratigraphic distribution of the identified assemblages.

\section{IM/Fosso 5 Agosto section}

The IM/Fosso 5 Agosto land section represents the uppermost part of Interval A in the Montalbano Jonico composite section (Ciaranfi et al., 2001). Nannofossil biostratigraphical analysis refers the section to the 'small' Gephyrocapsa Zone and to the lowermost part of the Pseudoemiliania lacunosa Zone (Maiorano et al., 2004). The section is $55 \mathrm{~m}$ thick and consists entirely of dark and light muddy sediments (Fig. 1).

Figure 2 displays the palaeoenvironmental conditions in which it was deposited (from Stefanelli et al., 2005, modified). Foraminiferal distribution suggests deposition of the pre- and post-sapropel stratigraphical intervals in a deep sedimentary basin, consistent with the upper bathyal zone (200-500 m water depth), under relatively 'cold' climate conditions (Stefanelli, 2004; Stefanelli et al., 2005).

The sapropel layer is enclosed in MIS 25. It is associated with i-cycle 90 and consists of a $6 \mathrm{~m}$ thick interval of dark mud 


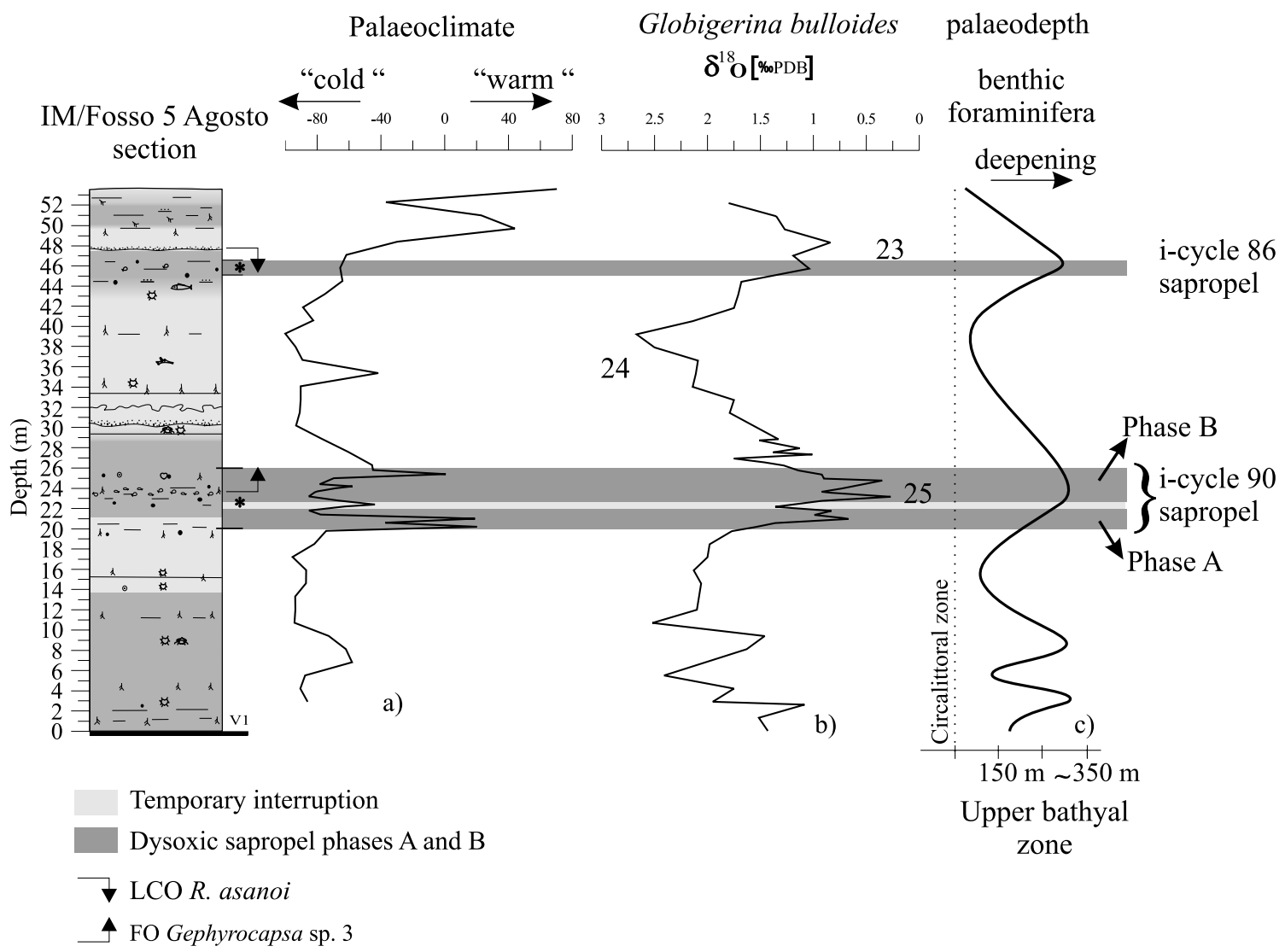

Fig. 2. (a) Palaeoclimate curve based on planktonic foraminifera; (b) oxygen stable isotope record performed on the planktonic foraminiferid species Globigerina bulloides; (c) changes in palaeodepth recorded by benthic foraminifera. Sapropel occurred during deepening phase. Grey-shaded intervals indicate dysoxic sapropel phases A and B. FO, first occurrence; LCO, last common occurrence. Modified from Stefanelli et al. (2005).

(Stefanelli et al., 2005). The continuous presence of benthic foraminifera across the sapropel suggests that the bottom was not totally anoxic. However, this layer exhibits two low oxygen phases, A and B. Both phases are characterized by warm climatic conditions together with freshwater input at the base, whereas, at the top, colder climatic conditions and a gradual mixing of the surficial water layers are documented. The identified phases are separated by a short re-oxygenation interval produced by a drop in temperature (Stefanelli et al., 2005).

\section{RESULTS}

\section{Foraminiferal fauna in Site 977A Core 18X-1, eastern Alboran Basin}

Benthic foraminifera (Fig. 3). The benthic foraminiferal microfaunas are well preserved with no barren samples. Sixty-four taxa were counted and identified; the maximum number of taxa identified per sample was 45 . For HCA, a raw data matrix made up of 25 samples $\times 32$ taxa was used.

Figure 4 records the outcome of HCA. The resulting dendrogram can be divided into the following clusters: Cluster A, Cluster B (divisible into subclusters B1 and B2), Cluster C and Cluster D. Figure 5 illustrates the cumulative plots of the benthic foraminiferal clustering. In the pre-sapropel interval $(156.68-156.34 \mathrm{rmcd})$, benthic foraminifera numbers (BFN) range between 38 ind. $\mathrm{g}^{-1}$ and 120 ind. $\mathrm{g}^{-1}$. Pre-sapropel diver- sities are rather high, with $H(S)$ values around 2.5. This interval is characterized by several taxa, principally grouped into Cluster A. Eponides pusillus is the dominant species, with a frequency of up to $50 \%$. Cassidulina crassa is also abundant, up to $20 \%$ of frequency. The associated taxa Globocassidulina subglobosa, Bulimina striata mexicana, B. marginata, Bolivina pseudoplicata, Cibicidoides group, Pullenia group and Sphaeroidina bulloides are present with low percentages of frequency (less than $4 \%$ ).

At approximately $156.36 \mathrm{rmcd}$, BFN decreases. The assemblages become more specialized and reach the minimum diversity and the maximum dominance values in the two intervals, $156.32-156.28 \mathrm{rmcd}$ and $156.26-156.24 \mathrm{rmcd}$, respectively. From $156.28-156.26 \mathrm{rmcd}$, BFN slightly increases and is associated with an increase in benthic faunal diversity, with $H(S)=2$.

In the sapropel interval, Bolivina catanensis (with a frequency up to $47 \%$ ), Globobulimina affinis (80\%), Articulina tubulosa and Cassidulina carinata (both $30 \%$ ) are the dominant taxa. The associated taxa Gyroidinoides group and Uvigerina peregrina (both with frequencies up to $10 \%$ ), Bolivina group, Buliminella elegantissima, Bulimina exilis, Chilostomella mediterranensis, Fissurina group, Lagena group and Trifarina anguolsa are rather scattered. These species are grouped in Clusters B and D (Fig. 4).

Bolivina catanensis, Globobulimina affinis, Articulina tubulosa and Cassidulina carinata never co-occur together. B. catanensis, which dominates the Cluster D assemblage, characterizes the 


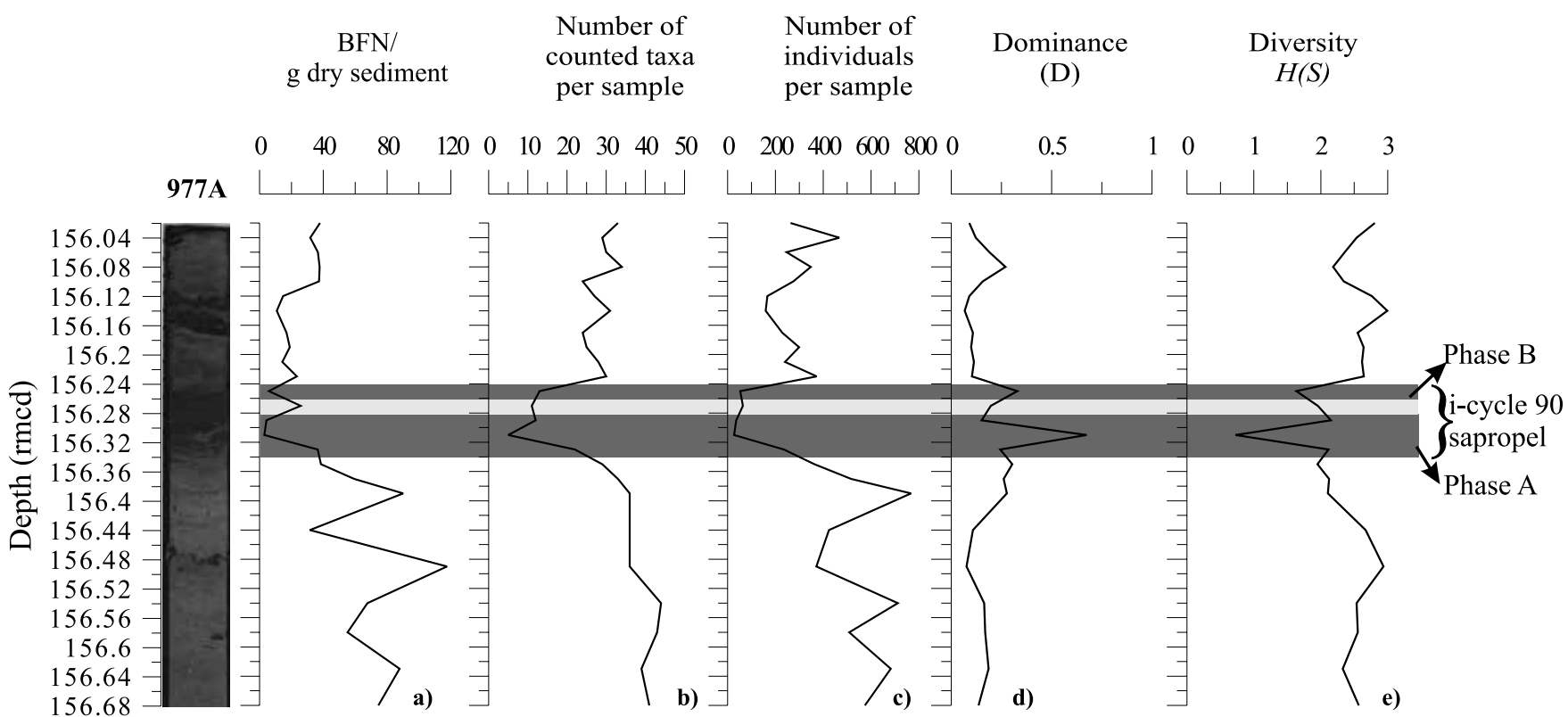

Fig. 3. Benthic patterns in Site 977A: (a) benthic foraminifera number (BFN) per gram of dry sediment; (b) number of counted taxa per sample; (c) number of total individuals counted per sample; (d) dominance (D); (e) species diversity $(H(S))$. All the graphs are plotted versus depth. Grey-shaded intervals indicate the sapropel phases A and B.

basal layer of the sapropel, from $156.34 \mathrm{rmcd}$ to $156.32 \mathrm{rmcd}$. $G$. affinis, which dominates the subcluster B2 assemblage, characterizes two layers, 156.32-156.28 rmcd and 156.26-156.24 rmcd, which are separated by a short layer $(156.28-156.26 \mathrm{rmcd})$ in which $A$. tubulosa and $C$. carinata are the most abundant benthic species belonging to the subcluster B1 assemblage.

From $156.24 \mathrm{rmcd}$ depth, in the post-sapropel stratigraphical interval, the fauna returns to being well diversified, with values similar to those observed in the pre-sapropel interval $(H(S)=2.5)$. The benthic foraminifera numbers are lower when compared with the pre-sapropel numbers. The assemblages are characterized by Anomalinoides minimus, Quinqueloculina group, Melonis group, Nonionella turgida, Bolivina variabilis, Epistominella exigua, Fursenkoina schreibersiana and Globocassidulina brady, all taxa grouped in Cluster C.

E. pusillus and the associated taxa of Cluster A are also present, with minor percentages of frequency with respect to the pre-sapropel interval (Fig. 5).

Planktonic foraminifera. Planktonic foraminiferal assemblages are abundant and diverse, some specimens are filled with pyrite and/or $\mathrm{CaCO}_{3}$. For HCA, a raw data matrix made up of 25 samples $\times 12$ taxa was used.

Figure 6 reports the resulting HCA dendrogram in which two clusters are recognizable: Cluster I and Cluster II. Cluster I groups Globigerinoides ruber alba, Globorotalia inflata, Globigerina rubescens, Globigerinoides tenellus and Orbulina universa. Cluster II groups Globigerina bulloides, Turborotalia quinqueloba, Globigerinita glutinata, Neogloboquadrina dutertrei, Neogloboquadrina pachyderma (dextral and sinestral), Globorotalia truncatulinoides and G. scitula.

Figure 7 displays the cumulative plots of the planktonic foraminifera clustering. In the pre- and post-sapropel stratigraphic intervals, the Cluster II assemblage is dominant, whereas the Cluster I assemblage characterizes the sapropel samples.

In the pre-sapropel stratigraphical interval, among the species grouped in Cluster I, Globigerina rubescens and Globigerinoides tenellus show their maximum peak in abundance. Between $156.68 \mathrm{rmcd}$ and $156.5 \mathrm{rmcd}$, Globigerina bulloides and Neogloboquadrina pachyderma dex are the most representative specimens, then they decrease in percentages (from $15-20 \%$ to $5-10 \%$, respectively) within the sapropel interval. Generally, $G$. ruber alba, T. quinqueloba and $G$. inflata are well represented. In detail, G. ruber alba displays its maximum peak in abundance at $156.32 \mathrm{rmcd}$ core depth, then it gradually decreases in the upper part of the sapropel; $G$. inflata increases towards the top of the sapropel and reaches its maximum abundance at $156.27 \mathrm{rmcd}$ and T. quinqueloba occurs with percentages around $20 \%$.

The peak in frequency of $N$. pachyderma $\sin , N$. dutertrei, $O$. universa and $G$. glutinata is significant between $156.30 \mathrm{rmcd}$ and $156.28 \mathrm{rmcd}$. In this short interval, these species increase in abundance, whereas G. inflata, T. quinqueloba and G. bulloides decrease. In the samples immediately above, between $156.279 \mathrm{rmcd}$ and $156.26 \mathrm{rmcd}, G$. inflata and N. pachyderma dex increase in abundance, while $N$. pachyderma sin, $N$. dutertrei, O. universa and G. glutinata decrease.

In the post-sapropel interval the assemblages are characterized by $G$. inflata (frequency $>20 \%$ ), G. bulloides $(>10 \%$ ) and $N$. pachyderma (dex and $\sin )(10-30 \%)$.

\section{Foraminiferal assemblages at Site 964 Core 4H-4, Ionian Sea}

Benthic foraminifera. Fifteen benthic taxa were counted and identified. The maximum number of taxa identified per sample is eight. The samples associated with the dark-coloured beds are barren of benthic foraminifera. The benthic foraminiferal faunal pattern is shown in Figure 8. 
Case Processing Summary ${ }^{\text {a. }}$

\begin{tabular}{|c|c|c|c|c|c|}
\hline \multicolumn{6}{|c|}{ Cases } \\
\hline \multicolumn{2}{|c|}{ Valid } & \multicolumn{2}{|c|}{ Missing } & \multicolumn{2}{|c|}{ Total } \\
\hline $\mathrm{N}$ & Percent & $\mathrm{N}$ & Percent & $\mathrm{N}$ & Percent \\
\hline 32 & $100 \cdot 0 \%$ & 0 & $0 \%$ & 32 & $100 \cdot 0 \%$ \\
\hline
\end{tabular}

a. Correlation between vectors of Values used

Dendrogram using Average Linkage (Within Group)

Rescaled Distance Cluster Combine

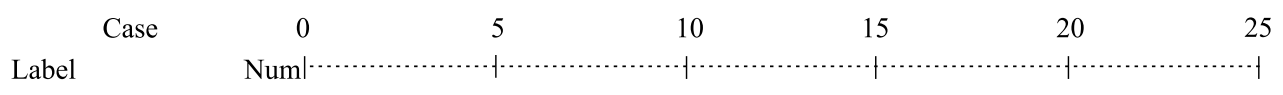

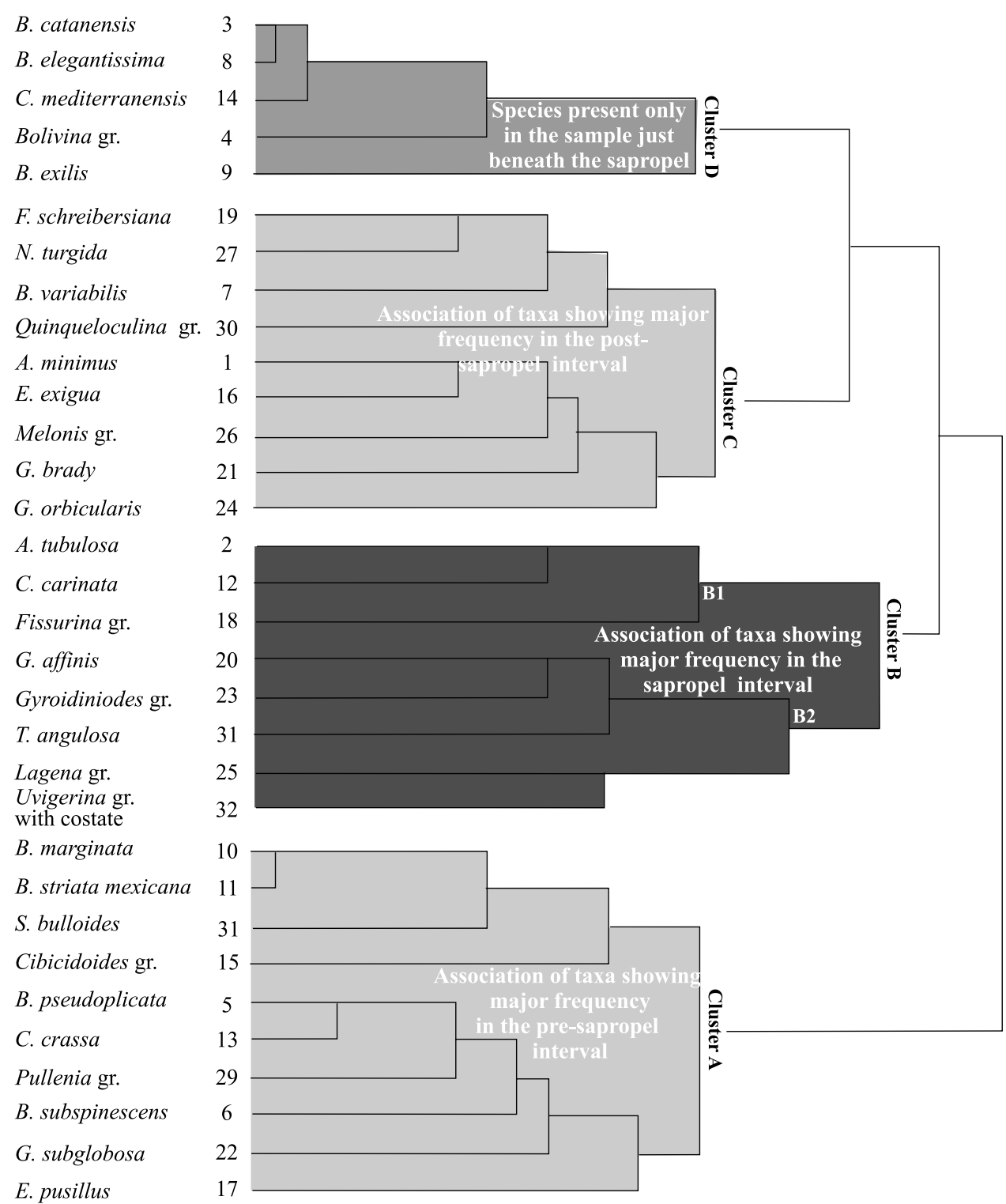

Fig. 4. Dendrogram based on R-mode cluster analysis by means of SPSS. Four clusters are identified: Cluster A, Cluster B, Cluster C and Cluster D. Cluster B is subdivided into two subclusters, B1 and B2. 


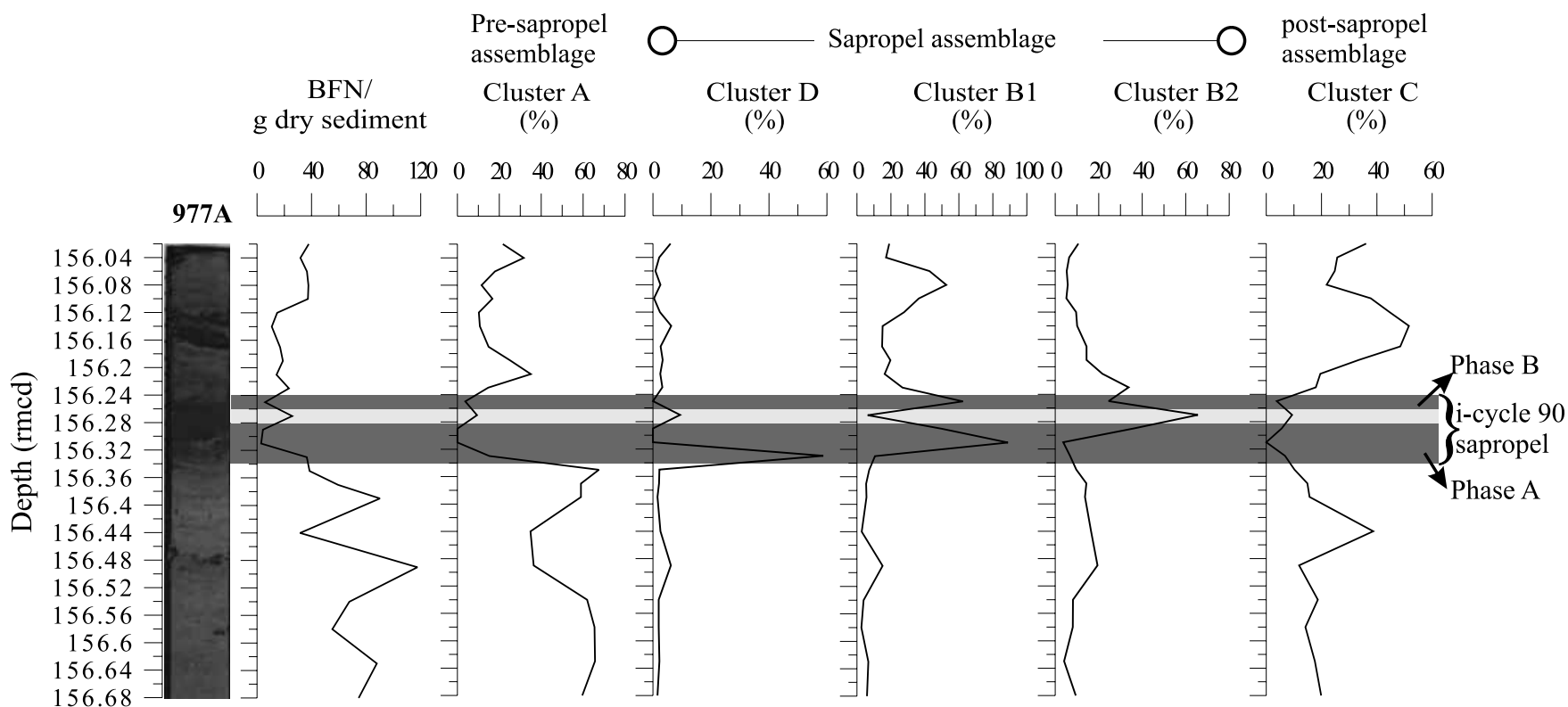

Fig. 5. Cumulative plots of clusters at Site $977 \mathrm{~A}$ plotted versus depth. Grey-shaded intervals indicate the sapropel phases A and B.

\begin{tabular}{|c|c|c|c|c|c|}
\hline \multicolumn{6}{|c|}{ Cases } \\
\hline \multicolumn{2}{|c|}{ Valid } & \multicolumn{2}{|c|}{ Missing } & \multicolumn{2}{|c|}{ Total } \\
\hline $\mathrm{N}$ & Percent & $\mathrm{N}$ & Percent & $\mathrm{N}$ & Percent \\
\hline 12 & $100 \cdot 0 \%$ & 0 & $0 \%$ & 12 & $100 \cdot 0 \%$ \\
\hline
\end{tabular}

Dendrogram using Average Linkage (Within Group)

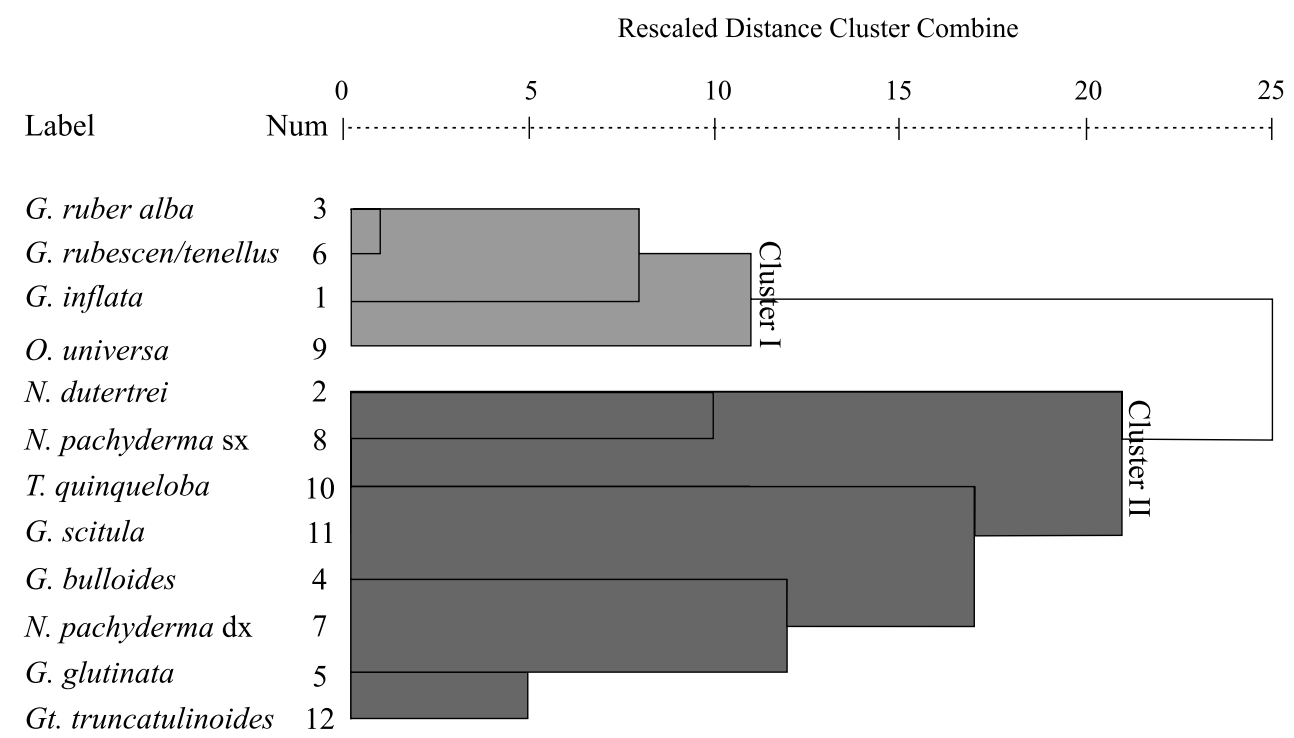

Fig. 6. Dendrogram based on R-mode cluster analysis by means of SPSS. Two clusters are identified: Cluster I and Cluster II.

Two species dominate the assemblages: Articulina tubulosa and Anomalinoides minimus, although they never co-occur in the same samples, with the exception of the last sample at the top of sapropel at $34.19 \mathrm{rmcd}$ depth (Fig. 9). Consequently, the dominance of only two species and the very low presence of associated taxa did not permit statistical analyses.
In the pre-sapropel interval, BFN average is 15 ind. $\mathrm{g}^{-1}$ on, except in the interval between $34.44 \mathrm{rmcd}$ and $34.38 \mathrm{rmcd}$, where the values increase up to 50 ind. $\mathrm{g}^{-1}$. Diversity is low and shows an increasing trend towards the sapropels, reaching the maximum value in the sample just below the sapropel, with $H(S)=1$, at $34.31 \mathrm{rmcd}$. A. tubulosa dominates the pre-sapropel interval 


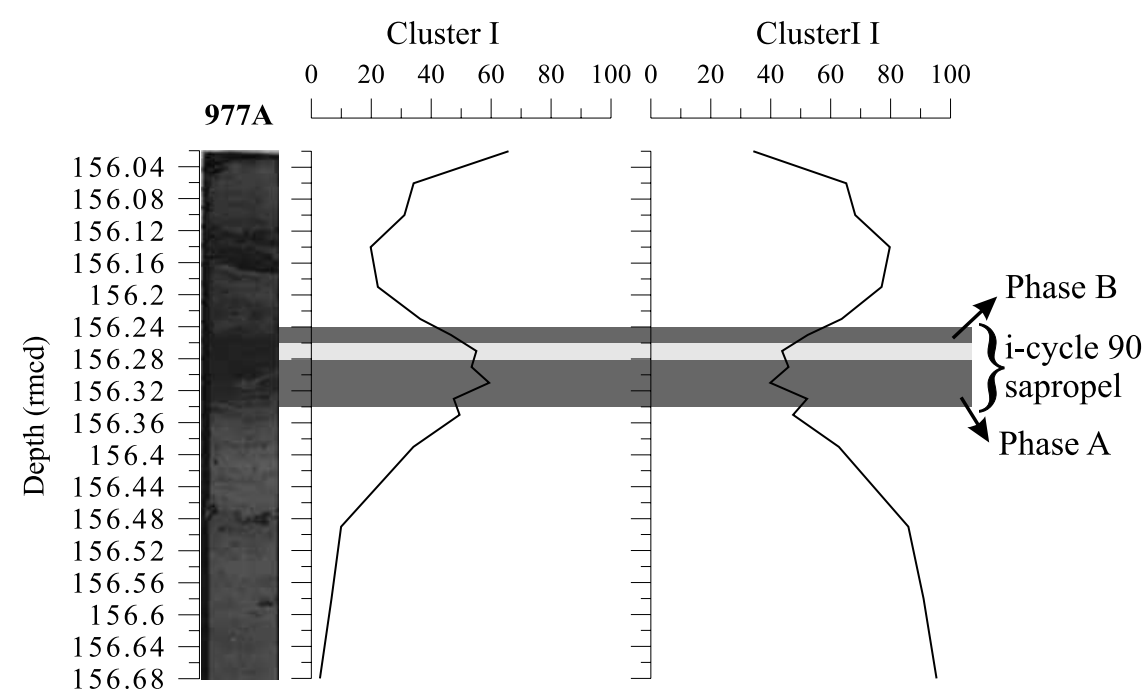

Fig. 7. Cumulative plots of clusters at Site 977A plotted versus depth. Grey-shaded intervals indicate the sapropel phases A and B.

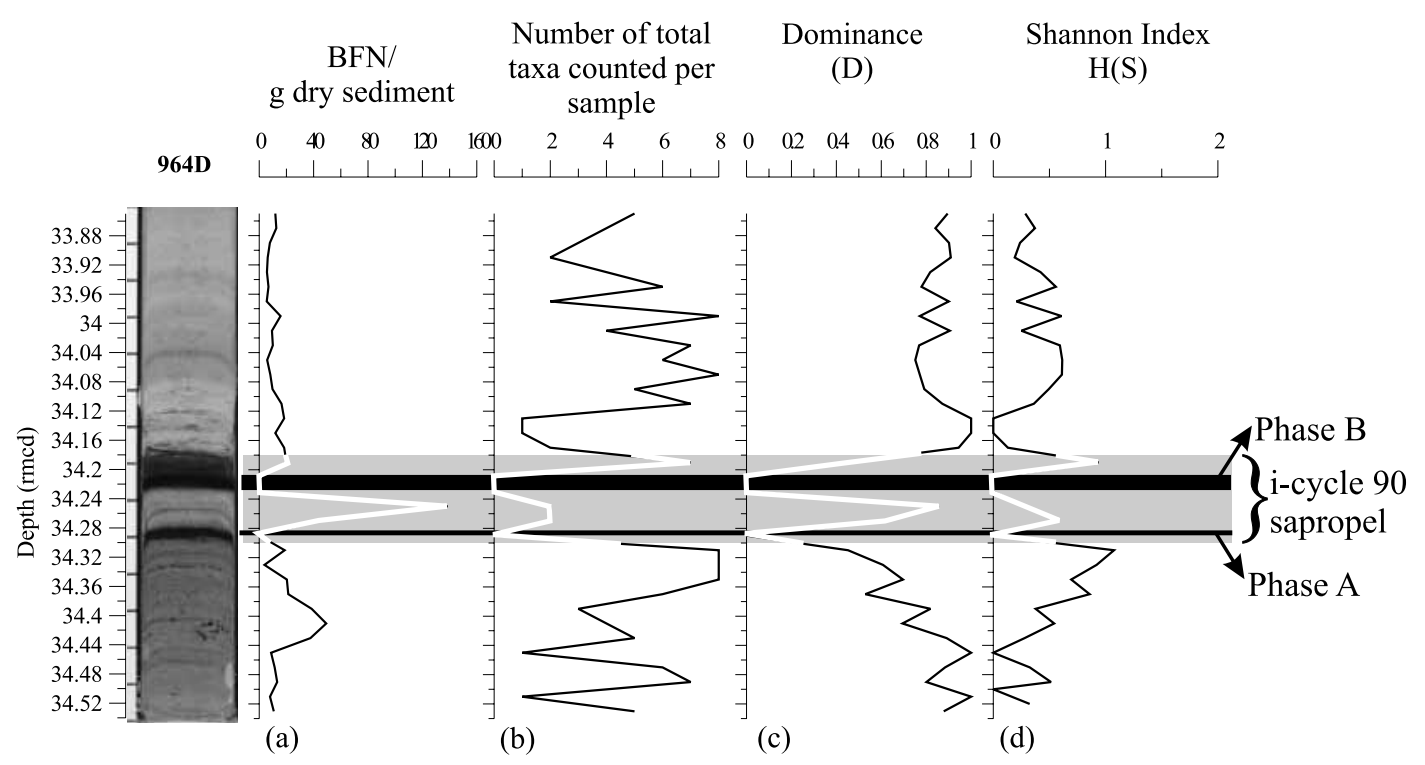

Fig. 8. Benthic patterns at Site 964D: (a) benthic foraminifera number (BFN) per gram of dry sediment; (b) number of counted taxa per sample; (c) dominance $(D)$; (d) species diversity $(H(S))$. All the graphs are plotted versus depth. Grey-shaded interval indicates the sapropel unit. Black colour indicates benthic sterile intervals (phases $\mathrm{A}$ and $\mathrm{B}$ ).

exclusively. Towards the sapropel, this species co-occurs with the genus Pyrgo, which has a frequency of $30 \%$. Quinqueloculina group is also present with very low frequencies $(<2 \%)$.

Within the sapropel interval, the samples associated with the two dark-coloured beds are barren of benthic foraminifera.

Between the dark-coloured beds, in the short interval 34.286$34.245 \mathrm{rmcd}$, BFN strongly increases, reaching its maximum values (138 ind. $\mathrm{g}^{-1}$ on average). In this short interval Anomalinoides minimus is the dominant species. Just before sapropel termination, (34.20-34.18 rmcd), above the second and uppermost dark-coloured bed, A. tubulosa and A. minimus co-occur, both with a frequency of $50 \%$.

In the immediately subsequent post-sapropel interval, Articulina tubulosa again dominates the assemblages.
Planktonic foraminifera. The dendrogram obtained by HCA cannot be interpreted as the clustering of the planktonic taxa did not allow palaeoecological interpretation. Opinion is that, probably, the low number of samples analysed for this stratigraphical interval did not give rise to a significative raw data matrix. Consequently, the quantitative distributional patterns of each taxon are discussed for Site 964D.

The distribution versus depth of the most abundant planktonic foraminifera and the palaeoclimate curve is shown in Figure 10.

Globigerinoides ruber, Globigerina bulloides, Globorotalia scitula, Globigerinita glutinata are the most typical species in the pre-sapropel interval. 


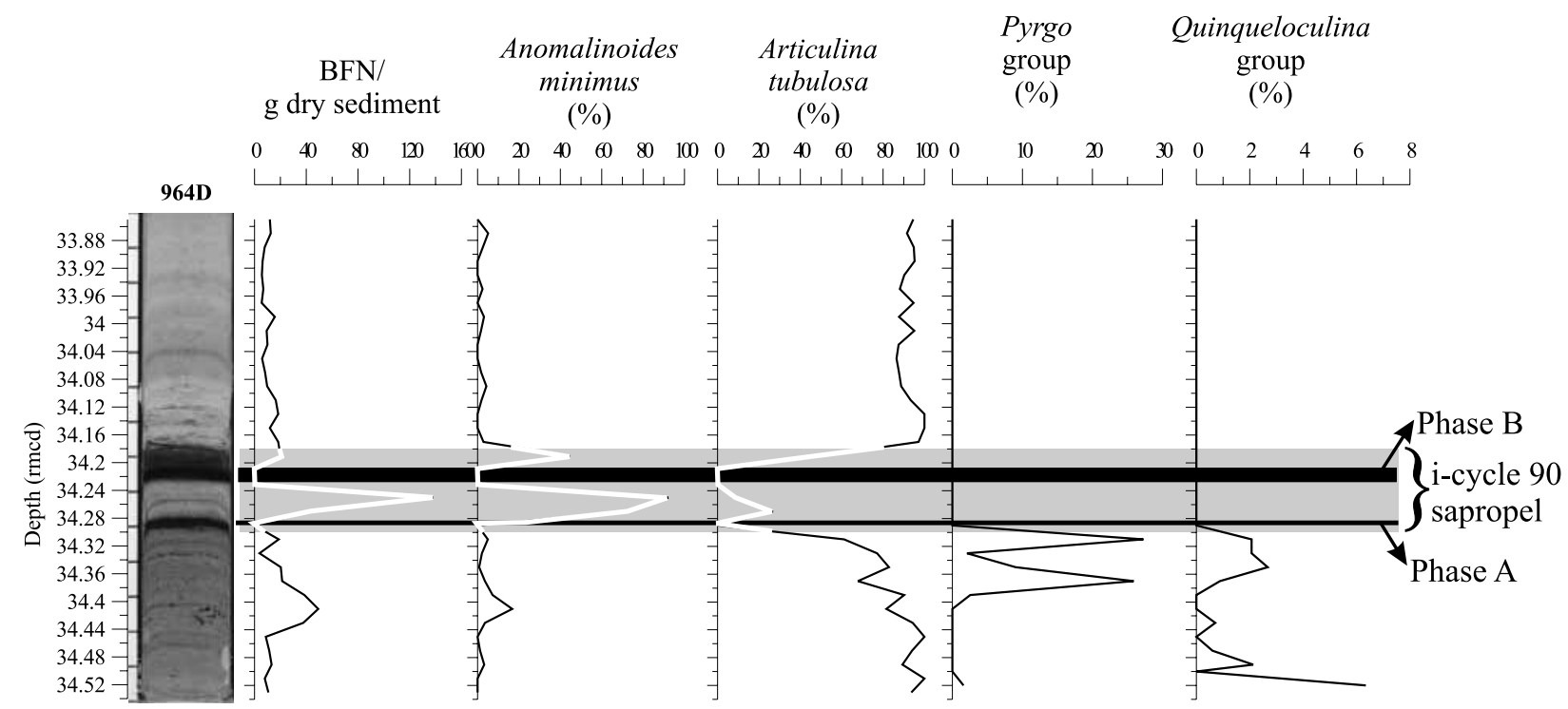

Fig. 9. Stratigraphic distribution of the dominant species Articulina tubulosa and Anomalinoides minimus at Site 964D plotted versus depth. The associated genera Pyrgo and Quinqueloculina are also displayed. Grey-shaded interval indicates the sapropel unit. Black colour indicates benthic sterile intervals (phases A and B).

The first dark-coloured layer is characterized by an increase in values of $N$. dutertrei, G. bulloides, N. pachyderma dex, T. quinqueloba and $O$. universa. The assemblage identified between the two dark-coloured intervals documents the strong decrease in T. quinqueloba, the near absence of G. glutinata and G. scitula, and an increase in N. pachyderma dex, G. inflata and G. bulloides. The second dark level contains a microfauna dominated by $G$. bulloides, G. ruber gr., G. glutinata and T. quinqueloba.

$G$. glutinata and $G$. bulloides dominate the post-sapropel assemblages. G. trilobus, generally absent in the investigated core section, occurred from $34.17 \mathrm{rmcd}$ and $33.9 \mathrm{rmcd}$. A peak in frequency of $N$. pachyderma dex and $G$. inflata is also observed.

\section{DISCUSSION}

The life strategies of most benthic foraminiferal species are well known from studies on their distribution pattern and the microhabitat of recent benthic foraminifera from the Mediterranean (Mullineaux \& Lohmann, 1981; Nolet \& Corliss, 1990; Jorissen et al., 1992, 1995; De Stigter et al., 1998; De Rijk et al., 1999; Jorissen, 1999; Schmiedl et al., 2000; 2003; Sgarrella \& Moncharmont Zei, 1993) and from other areas (Corliss, 1985; Mackensen \& Douglas, 1989; Corliss \& Emerson, 1990; Sen Gupta \& Machain-Castillo, 1993; Gooday, 1994; Loubere, 1997). Similarly well documented is the geographical and depth distribution of living planktonic foraminifera in the Mediterranean Sea (Pujol \& Vergnaud-Grazzini, 1995; Reiss et al., 1999). Information about the life strategies of the major benthic and planktonic species that characterize the assemblages in Holes 977A and 964D is reported in Appendix A and they are illustrated in Plate 1.

Foraminiferal number, diversity and distribution in the western and eastern Mediterranean: ecosystem variability prior to, during and after the sapropel deposition

Across the Mediterranean Sea, benthic foraminifera frequency decreases from the high values encountered at Hole 977A
(60 ind. $\mathrm{g}^{-1}$ on average) to very low values at Hole 964D (15 ind. $\mathrm{g}^{-1}$ on average). This trend can be explained in terms of food availability, which decreases with increasing water depth (from $1984 \mathrm{~m}$ at $977 \mathrm{~A}$ to $3666 \mathrm{~m}$ at 964D), as previously documented by several authors (Cita \& Zocchi, 1978; Parisi, 1981; Parisi \& Cita, 1982; De Rijk et al., 1999). Similarly, diversity decreases strongly with increasing depth, from $H(S)=3$ in the middle bathyal 977A, towards $H(S)<1$ in the deepest 964D. These observations corroborate previous studies carried out in the Mediterranean Sea, which reported unusually lowdiversity faunas in the lower bathyal and abyssal ecosystems (Cita \& Zocchi, 1978; Mullineaux \& Lohmann, 1981) under oligotrophic and well-oxygenated conditions (Pickard \& Emery, 1990; Antoine et al., 1995) and high-diversity faunas in the middle/upper bathyal and shelf ecosystems (Schmiedl et al., 2000; 2003) under meso- to eutrophic conditions.

In western Site 977A, before the sapropel deposition, the stability of the deep-sea ecosystem favoured the development of the highly diverse Cluster A assemblage under meso- to eutrophic conditions. The distinct vertical microhabitat preferences, from epifauna to shallow infauna observed in the presapropel assemblage also reflect a (palaeo)environmental setting with high oxygen content at the bottom-water interface that can reach deep layers within the sediment column (Loubere, 1997). Accordingly, the occurrence of $G$. inflata and, in some levels, of G. truncatulinoides documents the presence of a water column with deep convective mixing.

The cumulative plots of Clusters I and II performed on planktonic microfauna mirror the palaeoclimate curve sensu Lourens et al. (1992) (see Fig. 6), based on selected warm-water (Globigerinoides tenellus, G. ruber, Globigerina rubescens, Orbulina universa - Cluster I) and cold-water species (Globigerina bulloides, Globorotalia scitula, Neogloboquadrina pachyderma dex and sin, Globigerinita glutinata and Turborotalia quinqueloba - Cluster II). This suggests that the temperature and/or seasonality are two important factors influencing the 

Palaeoclimate
G. ruber
O. universa
G. rubescens/
(\%)
(\%)
G. tenellus
$(\%)$
G. trilobus
$(\%)$
T. quinqueloba N. dutertrei
(\%)
(\%)

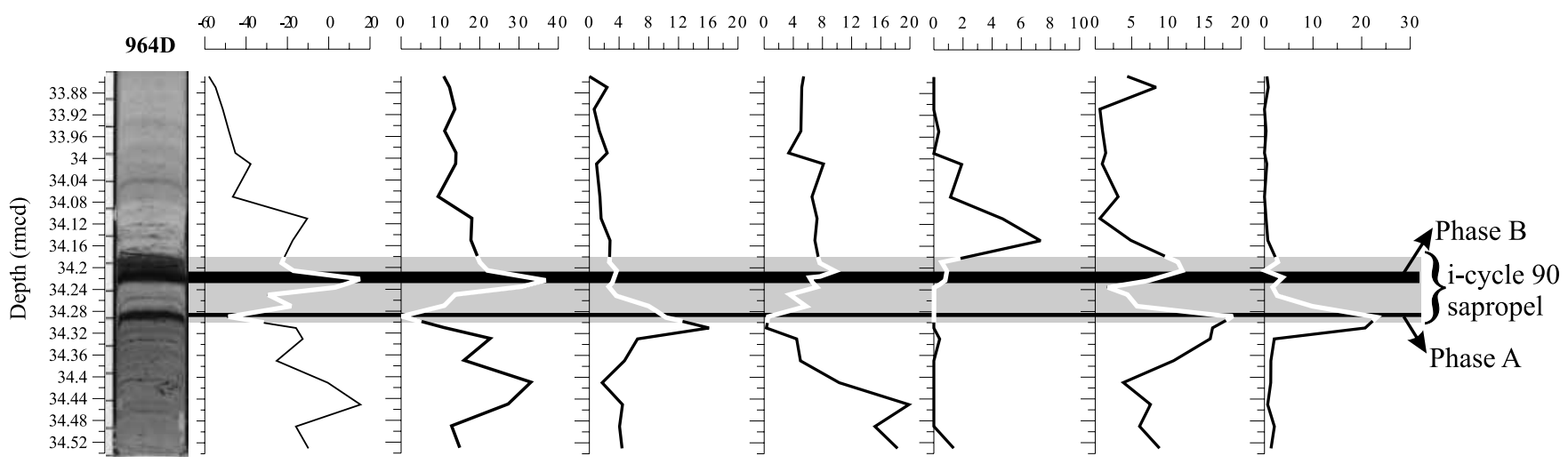

Palaeoclimate

$\begin{array}{cccc}\begin{array}{c}\text { G. bulloides } \\ (\%)\end{array} & N \text {. pachyderma } N \text {. pachyderma } & \text { G. scitula } \\ \mathrm{dx}(\%) & \text { sx }(\%) & (\%)\end{array}$

G. glutinata

G. inflata

(\%)

$(\%)$

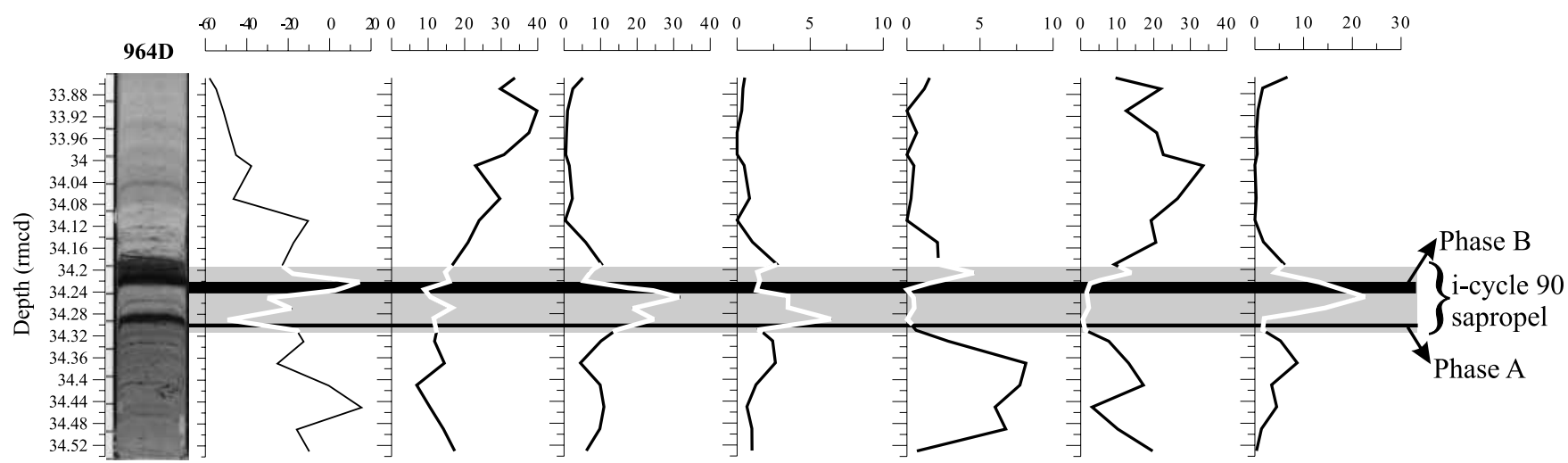

Fig. 10. Stratigraphical distribution of selected planktonic foraminifera species at Site 964D plotted versus depth. Palaeoclimate record is also shown. Grey-shaded interval indicates the sapropel unit. Black colour indicates benthic sterile intervals (phases A and B).

planktonic assemblage composition and distribution in this time interval. Focusing in detail, the palaeoclimate curve shows an increase in temperature of the water masses beginning several samples prior to sapropel deposition, at $156.5 \mathrm{rmcd}$ (see Fig. 7).

Just before sapropel deposition, the observed increase in numbers of G. ruber and G. tenellus/G. rubescens, which culminates within the sapropel, as well as the simultaneous slight decrease of G. bulloides and N. pachyderma, suggest the presence of warm, low surficial water density with consequent increase in stratification. However, the environmental deterioration was not drastic enough to stop seasonal vertical mixing, as evidenced by the presence of $G$. inflata. Also, no persistent anoxia developed at the bottom, as documented by the persistent presence of benthic foraminifera throughout the sapropel interval.

The rhythmical succession in benthic foraminifera sapropel assemblages can be interpreted as a response to the continuous changes in oxygen content of the bottom water, allowing identification of distinct sapropel phases. The dominance of $B$. catanensis in the lower part of the sapropel interval, later replaced by $G$. affinis, implies the gradual thinning of the oxygenated top layer of the sediments during the development of the first sapropel phase (phase A). The replacement of $A$. tubulosa and C. carinata by the dysoxic species G. affinis documents short oxygenation pulses under unstable environmental conditions (Schmiedl et al., 1998; Jorissen, 1999). Finally, the replacement of $G$. affinis in the upper part of the sapropel interval by $A$. tubulosa and C. carinata suggests the re-establishment of the sapropel condition still under a dysoxic regime (phase B).

The presence of the genera Articulina and Cassidulina throughout the sapropel documents a short interval characterized by oxygen replenishment at the seafloor. In these samples, the peak in frequency of the cool taxon G. inflata and the increase in abundance of G. bulloides and N. pachyderma dex document the drop in temperature that probably drove a vertical water mixing and, hence, the oxygen increase at the bottom-water interface.

During the onset of the second sapropel subunit, the lower abundance of G. affinis (from $80 \%$ in the first subunit to $60 \%$ detected in the second subunit) and the increase in frequency of C. carinata and A. tubulosa (from $2 \%$ in the first subunit to $20 \%$ detected in the second subunit) clearly suggest an improved 


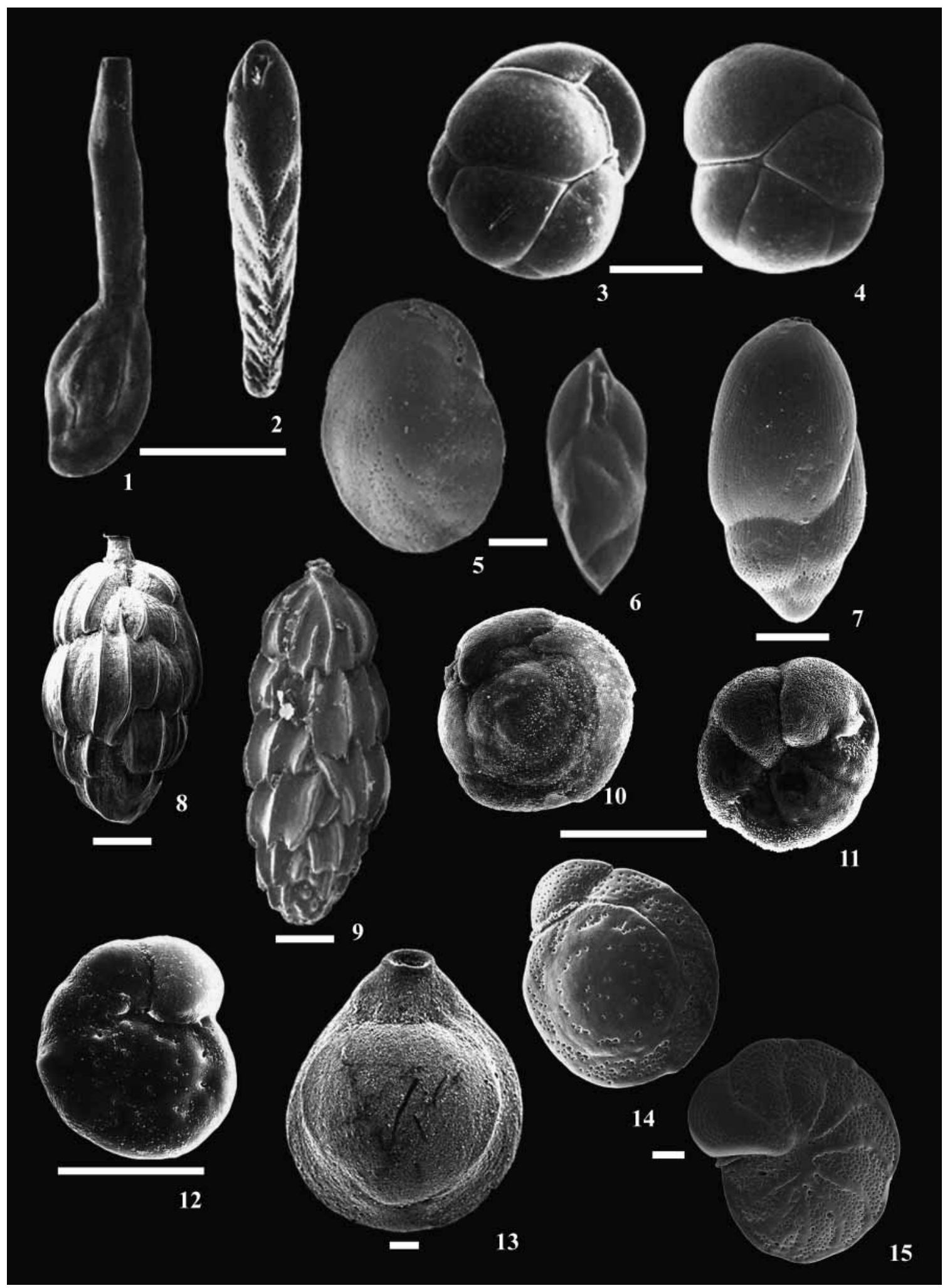

Explanation of Plate 1.

The most (palaeo)ecologically significant benthic species encountered in this work (scale bar 100 micron). fig. 1. Articulina tubulosa (Seguenza, 1862). fig. 2. Bolivina catanensis Seguenza, 1862. figs 3-4. Cassidulina crassa d'Orbigny, 1839. figs 5-6. Cassidulina carinata (Silvestri, 1896 ). fig. 7. Globobulimina affinis d'Orbigny, 1839. fig. 8. Uvigerina mediterranea Hofker, 1932. fig. 9. Uvigerina peregrina Cushman, 1923. figs 10-11. Eponides pusillus Parr, 1950. fig. 12. Anomalinoides minimus Vismara-Schilling \& Parisi, 1981. fig. 13. Pyrgo lucernola (Schwager, 1866). figs 14-15. Cibicidoides pachyderma (Rzeahk, 1886). 
oxygen concentration at the bottom. The increase in frequency of $G$. scitula and T. quinqueloba and the decreasing of G. ruber alba suggest an ameliorate ventilation in the water column and an increased superficial water productivity.

$G$. inflata is absent in many Late Quaternary sapropel layers due to the lack of mixing in the water column, with year-round stratification (Capotondi et al., 2000). In 977A, the continuous presence of $G$. inflata within the sapropel could indicate a seasonal contrast, concluding that sapropel deposition occurred strictly in the summer period.

Immediately after deposition of the sapropel, benthic foraminiferal diversity is similar to the pre-sapropel value. This observation suggests a high recovery potential of benthic species as soon as the (palaeo)environmental conditions improve. Thus, the relative increase in $N$. pachyderma and $G$. bulloides, the presence of $G$. scitula and the minor values of $G$. ruber are evidence of cooling of the water masses. This led to the break in water-mass stratification that characterizes the end of the sapropel, thus facilitating vertical mixing in the water column, with consequent oxygen renewal in the deepest bottom layers.

The lower BFN recorded in the post-sapropel interval, with respect to the pre-sapropel values, probably reflects different trophic conditions, related to the transition from glacial sediments (termination of MIS 26 prior to the sapropel) to interglacial (beginning of MIS 25 after the sapropel). This theory is based on the observations of Schmiedl et al. (1998) from the study of benthic foraminifera distribution in a long core from the Ionian Sea. They observed that the glacial sediments are characterized by enhanced productivity and organic matter fluxes to the seafloor that led to an increase in the number of foraminifera. By contrast, in interglacial sediments, productivity and organic matter fluxes are low, determining a decrease in the number of benthic foraminifera.

In the eastern Mediterranean Site 964D, the pre- and postsapropel intervals are dominated by the normal oligotrophic deep-assemblage - of which $A$. tubulosa is the most representative species - indicating a stable deep-sea ecosystem (Mullineaux \& Lohmann, 1981; Jorissen, 1999; De Rijk et al., 1999). The similar benthic foraminiferal diversity and number observed in pre- and post-sapropel intervals means that at the greatest depths foraminifera showed a high potential for recovery when the sapropel ended.

At the time of sapropel deposition, the whole fauna disappears because the oxygen content at the bottom-water interface and in the sediment column is too low to support benthic life.

During the onset of the first sapropel subunit (phase A), the palaeoclimate curve reveals cold conditions. The peak in frequency of $N$. dutertrei and $T$. quinqueloba documents the presence of a low density water mass and a highly stratified column, with high nutrients and terrestrial organic material input. As is well known, $N$. dutertrei characterizes the sapropel assemblages in colder climate conditions (Capotondi \& Vigliotti, 1999; Negri et al., 1999). This species is observed commonly with a relatively high percentage of abundance in Late Quaternary sapropels, together with $N$. pachyderma. Their presence has been interpreted as the seasonally shallowing of the thermocline within the photic zone, indicating the presence of the deep chlorophyll maximum and stratified conditions in the euphotic layer (Rohling et al., 1997).

During the onset of the second sapropel subunit (phase B), the co-occurrence of $G$. ruber and $G$. scitula could testify a strong seasonal contrast and/or thermal and density stratification in the water column. This reconstruction is also suggested by the palaeoclimate curve characterized by the dominance of G. ruber, which usually occurs in sapropels associated with a strong reduction in ventilation and a low salinity surface water layer (Bè \& Tolderlund, 1971; Thunell, 1978).

In a similarly hostile scenario, the occurrence of $A$. minimus restricted between the two distinct anoxic phases can be interpreted as an interruption in sapropel deposition. Subsequently, these data document that also at greatest depth sapropel results interrupt. A. minimus was able to colonize the deep basin rapidly during short intervals of improved oxygenation and seasonal food pulses, as observed also by Jorissen (1999), Oggioni \& Zandini (1987) and Schmiedl et al. (2003). The absence of the classical infaunal taxa (Fursenkoina, Globobulimina, Bulimina), which one would have expected here, suggests that food fluxes were too low to support their existence. The maximum frequency reached by $G$. inflata implies that sapropel interruption was driven by a short-term climate change, as previously hypothesized for Site 977A, producing vertical water mixing with consequent oxygen replenishment at the bottom-water surface.

By the termination of sapropel, the planktic assemblage is characterized by an increase in $G$. trilobus, suggesting the presence of a shallow pycnocline. The occurrence of $G$. inflata and $G$. scitula documents a break in water-mass stratification. Finally, the dominance of G. bulloides and G. glutinata and T. quinquelobalhumilis suggests a nutrient enrichment in the photic zone, probably related to continental input.

Foraminiferal investigation carried out in the IM/Fosso 5 Agosto section documents a gradual decrease in bottom-water oxygenation prior to the onset of sapropel deposition and a rapid return to stable environmental conditions at the end of the stagnation event (for details, see Stefanelli et al., 2005). The distribution pattern of planktonic and benthic foraminifera within the sapropel suggests a surface-water cooling, with consequent rapid re-oxygenation of bottom waters, which subdivides the sapropel into two phases (A and $\mathrm{B}$ ). Both phases are characterized by an early subphase with warm climate conditions, a decrease in salinity in surficial water layers and are dominated by the low oxygen-tolerant benthic species Globobulimina affinis. The late subphase shows thermal stratification during summer and a relatively deep and oxygenated mixed layer during winter. In this subphase the contemporaneous replacement of the 'less opportunistic, but more resistant to low oxygen conditions' species Globobulimina affinis by Bolivina alata, B. dilatata and Brizalina spathulata, all 'less resistant to low oxygen conditions' species indicates a relative oxygen improvement in sediment pore-water.

\section{I-cycle 90 coeval sapropels from different Mediterranean locations and its palaeoceanographic scenario}

Figure 11 shows the benthic foraminifera distribution across the i-cycle 90 sapropel intervals recorded at the ODP Sites and at the IM/Fosso 5 Agosto land section. 


\begin{tabular}{|c|c|c|c|}
\hline $977 \mathrm{~A}$ & $\begin{array}{l}\text { Montalbano Jonico } \\
\text { composite section }\end{array}$ & $964 \mathrm{D}$ & \\
\hline Alboran Sea & South Adriatic & Ionian Sea & \\
\hline A. minimus & $\begin{array}{l}U . \text { mediterranea/ } \\
U \text {. peregrina }\end{array}$ & A. tubulosa & $\begin{array}{l}\text { post-sapropel } \\
\text { interval }\end{array}$ \\
\hline G. affinis & Bolivina & $\begin{array}{l}\text { A. tubulosa/ } \\
\text { A. minimus }\end{array}$ & Phase B \\
\hline U. agjonis & G. affinis & sterile & Fnase B \\
\hline $\begin{array}{l}\text { A. tubulosa/ } \\
\text { C. carinata }\end{array}$ & $\begin{array}{l}\text { C. carinata } \\
U \text {. peregrina }\end{array}$ & A. minimus & $\begin{array}{c}\text { Sapropel i-cycle } 90 \\
\text { interval }\end{array}$ \\
\hline G. affinis & Bolivina & \multirow{2}{*}{ sterile } & \multirow[b]{2}{*}{ Phase A } \\
\hline Bolivina & G. affinis & & \\
\hline E. pusillus & C. carinata & A. tubulosa & $\begin{array}{l}\text { pre-sapropel } \\
\text { interval }\end{array}$ \\
\hline
\end{tabular}

Fig. 11. Species-key distribution across the pre-sapropel, sapropel and post-sapropel intervals in the investigated Mediterranean areas.

Transition from non-sapropel to sapropel stage. Focusing on non-sapropel to sapropel transition, benthic foraminifera suggest that the transition occurs differently in the different marine ecosystems.

At $400 \mathrm{~m}$ and $1984 \mathrm{~m}$ water depths, when an extreme oxygen deficiency occurred up to the sediment surface, deep infauna and low-oxygen-tolerant taxa, such as Bolivina group and G. affinis, replace the shallow infaunal and the epifaunal species, which disappear from the assemblage because they are less tolerant of low oxygen conditions. This biological substitution implies a regular transition from oxic to dysoxic conditions over a relatively long period of time, which allowed the deep infaunal species to take over the foraminiferal assemblages gradually. This reconstruction is in accordance with the observations of Jorissen (1999) about the faunal development associated with the deposition of S1 at shallow depth (<1250 m water depth).

The absence of deep infaunal species at $3666 \mathrm{~m}$ water depth in the sediments prior to i-cycle 90 sapropel formation is interpreted as a consequence of the low trophic conditions that did not allow the downward expansion of the bathymetrical range of the deep infaunal species to this water depth. At the time of sapropel formation, when primary productivity increases, deep infaunal species are absent, although the enrichment in organic matter at the dysoxic/anoxic boundary would be sufficient for the downward expansion of their bathymetric range. According to Jorissen (1999), this is interpreted as the response to a very rapid anoxic condition onset that does not allow deep infaunal species to colonize the bottom at $3666 \mathrm{~m}$.

Sapropel interruption. During sapropel deposition, the benthic foraminifera distribution documents brief oxygen replenishment at the seafloor, which divides the layer into two phases (A and B). The study of planktonic foraminifera indicates that this feature is linked to the cold climatic phase and to vertical mixing of the surficial and intermediate water masses.

The consequent oxygen replenishment at the seafloor is testified by the presence of different taxa in the investigated sites. Infaunal and epifaunal species, such as $C$. carinata and $B$. marginata, were found in the IM/Fosso 5 Agosto land section, C. carinata and A. tubulosa in Site 977A and A. minimus in Site 964. All these species are described as opportunistic, suggesting that the improvement in marine ventilation was very rapid, nearly instantaneous.
The interruption of the time-equivalent sapropel interval has already been documented in other ODP sites from different water depths and hydrographic settings (Bernasconi \& Pika-Biolzi, 2000; Hassold et al., 2003; Meyers \& Arnaboldi, 2005; Meyers \& Bernasconi, 2005). This means that the synchronous water cooling observed in this study corroborates well the hypothesis of Meyers \& Arnaboldi (2005). They argued that the interruption must have been a trans-Mediterranean phenomenon and that the interruptions record brief excursions out of the periods of wet climate associated with precessional minima.

Transition from sapropel to non-sapropel stage. The history of the re-colonization of the seafloor at the end of the sapropel deposition is observed to be similar at the three studied sites. The major frequency in abundance of the opportunistic shallow infaunal species $U$. peregrina/ $U$. mediterranea in the IM/Fosso 5 Agosto land section, and of the opportunistic epifaunal species A. minimus in Site 977A and A. tubulosa in Site 964D, suggests that the re-oxygenation was very rapid, almost instantaneous (Jorissen, 1999).

Benthic and planktonic foraminiferal patterns indicate that the process of re-oxygenation, modulated by the gradual cooling of the water, was not synchronous in all places. In Site 977A and in the land section, the re-oxygenation was coincident with the end of i-cycle 90 sapropel formation, but at greater depth, it occurred just before the end of sapropel deposition. In the deepest ecosystem, as soon as the stagnant conditions begin to dissipate, A. minimus and A. tubulosa were able to colonize the re-oxygenated habitats very quickly, before the return to normal oligotrophic conditions characterized by the dominance of $A$. tubulosa. This environmental reconstruction is in agreement with the observations reported by Jorissen (1999), Schmiedl et al. (2003) and Capotondi et al. (2006) concerning the re-oxygenation of the seafloor at the end of sapropel S5, deposited in the eastern deep ecosystems.

The results here partially support the assumptions of the above-mentioned authors about the effect of water depth on the severity of sapropel expression. The severity in oxygen depletion during i-cycle 90 sapropel deposition increases with increasing water depth (from $400 \mathrm{~m}$ at the IM/Fosso 5 Agosto land section and $1984 \mathrm{~m}$ at Site $977 \mathrm{~A}$, to $3666 \mathrm{~m}$ at $964 \mathrm{D})$.

Using the palaeocirculation model of Myers \& Rohling (2000) for the timing of sapropel formation, it is hypothesized that the lowering of surface salinity - which would decrease the density of the surface waters and, hence, reduce the potential for convective overturning and deep-water formation - was mitigated in the Alboran Basin and in the northern part of the Ionian Basin nearest the Adriatic Sea. Irrespective of the massive change in climatic conditions associated with the precessional minima, the constant inflow of Atlantic Water and of the water mass coming from the North Adriatic Sea may have reduced the dilution of the surface/intermediate water by the continental runoff. This implies that, in the Alboran Basin, the anti-estuarine circulation was weak and, since water-column ventilation remained feasible during the period of i-cycle 90 deposition, the deep-water formation did not completely cease and intermittent oxygen pulses arrived at the bottom.

In the Ionian Basin, at shallow water depth, the seafloor was overlain directly by the less diluted intermediate water; 
therefore, stagnant conditions never occurred. By contrast, at greatest depth the intermittent oxygen pulses did not arrive at the bottom, producing an anoxic deep-water layer.

\section{CONCLUSIONS}

High resolution analysis of benthic and planktonic foraminifera throughout a sapropel corresponding to insolation cycle 90 was performed in three different oceanographic and depositional settings (Alboran Basin, South Adriatic Sea and Ionian Sea) of the Mediterranean Sea.

The faunal successions provide information about the conditions leading to sapropel deposition and evidence some differences related principally to the different water depths of the basins and to the local oceanographic regime. In all investigated basins sapropel 90 is interrupted and two subphases (phase A and phase B) are identifiable.

At depths $>3000 \mathrm{~m}$ the absence of benthic microfauna documents stagnant conditions. The mechanism that led to the onset of the first sapropel phase A is linked to the increase in primary productivity, whereas the second sapropel phase B results are associated with the different density of the water masses.

During the onset of the sapropels at depths $<2000 \mathrm{~m}$ (in Site 977A and in the IM/Fosso 5 Agosto section) the water-mass stratification was not sufficiently strong to determine anoxia at the bottom and hence to stop benthic life. In both sites, the upper half of the sapropel layer records less severity with respect to the lower half. It is hypothesized that the surface water was cooler and that the increase in primary productivity was the mechanism that caused the onset of the second sapropel phase. However, this should not preclude the minor water depths of deposition that could favour the bottom ventilation present in later phase B of i-cycle 90 sapropel formation.

Foraminiferal content and distribution document that in all the investigated sites the short interruption was related to climatic deterioration, to a break in stratification and to a re-oxygenation of the bottom waters. This event appears to be correlated with the short-term climate variability already documented by Schmiedl et al. (2003 and references therein), thus confirming that i-cycle 90 sapropel interruption is a transMediterranean phenomenon.

\section{ACKNOWLEDGEMENTS}

The authors wish to thank M. Pika -Biolzi and the anonymous reviewer for their suggestions and valuable comments for the improvement of the manuscript. They are grateful to the Ocean Drilling Program (ODP) for providing samples for this study. Financial support was provided by University of Bari Grant ex $60 \%$ (2005) to Prof. N. Ciaranfi concerning the project Le variazioni climatiche nel record geologico del Pliocene superiore e del Pleistocene inferiore dell'Italia meridionale'. This is ISMAR-BO-CNR contribution n. 1571.

\section{APPENDIX A: (Palaeo)ecological meanings of the foraminifera species encountered in this study}

\section{Benthic foraminifera}

Articulina tubulosa

Anomalinoides minimus and Eponides pusillus

Bolivina catanensis, Cassidulina carinata and

C. crassa

Cibicidoides pachydermus

Globobulimina affinis

Planktonic foraminifera

Globigerinoides ruber
The most prominent representative species in the group of the miliolid taxa, indicative of oligotrophic and well-ventilated Mediterranean deep-sea environments (Jorissen, 1999). Small, epifaunal, opportunistic species, indicative of a high trophic level in combination with sufficiently high oxygen concentrations. These species, together with Epistominella exigua, co-occur in the bathyal and abyssal assemblages of the eastern Mediterranean.

Opportunistic species with a shallow to intermediate infaunal microhabitat, common in mesotrophic to eutrophic environments with moderate oxygen depletions in the bottom and in pore-water. Bulimina marginata, B. striata mexicana, Gyroidinoides soldanii, Hyalinea balthica and Melonis barleanum are also reported in this group.

Epifaunal species more or less opportunistic, adapted to high oxygen conditions and reported to be intolerant of environmental stress, in particular oxygen deficiency at the bottom (van der Zwaan, 1983). In the western Mediterranean Sea, its distribution is associated with oligotrophic and well-ventilated conditions. Schmiedl et al. (2000) observed a decrease in its number in favour of infaunal taxa at higher trophic level. Gyroidinoides orbicularis shows a similar life strategy, although it also occurs in significant numbers at higher trophic levels of the bathyal continental slope (Schmiedl et al., 2000).

Species with a deep infaunal microhabitat, especially resistant to very low oxygen conditions (Jorissen, 1999). It is common in low-oxygen habitats or eutrophic continental margins where it feeds from degraded organic matter at the dysoxic/anoxic boundary (Corliss, 1985; Mackensen \& Douglas, 1989; Schmiedl et al., 2000). In the case of a 'normal' situation, with a well-oxygenated sediment-water interface, G. affinis lives at considerable depth (several centimetres) in the sediment, often in completely anoxic conditions (Jorissen, 1999). Together with G. affinis, also reported as associated species are Bulimina exilis, Chilostomella spp. and Fursenkoina spp.

Oligotrophic shallow-dwelling species $(0-50 \mathrm{~m})$ that prefers tropical and warm subtropical water masses (Bè \& Tolderlund, 1971). In the Mediterranean Sea, this species proliferates at the end of the summer when the surface waters are well stratified (Pujol \& Vergnaud-Grazzini, 1995). It is also related to the low surficial salinity (Bè \& Tolderlund, 1971; Thunell, 1978). 
Cycle 90 sapropel; foraminiferal response

Orbulina universa

Globigerina rubescens/ Globigerinoides tenellus Globigerina bulloides

Globorotalia scitula Globorotalia inflata

Globigerina quinqueloba

Globigerinita glutinata

Neogloboquadrina pachyderma A deep dwelling species (>100 m) living close to, or below, the thermocline (Fairbanks \& Wiebe, 1980) and preferring depths where water temperatures are colder.

Neogloboquadrina dutertrei A deep dwelling species $(c .100 \mathrm{~m})$ living near the base of the local thermocline and associated with the presence of the DCM (Rohling \& Gieskes, 1989). The species is linked closely to shallowing of the thermocline to within the photic zone, which enhances productivity of $N$. dutertrei. High percentages of the species characterize sapropel assemblages in colder climate intervals (e.g. sapropel 6).

\section{Manuscript received 11 September 2006 Manuscript accepted 8 January 2008}

\section{REFERENCES}

Antoine, D., Morel, A. \& André, J.M. 1995. Algal pigment distribution and primary production in the eastern Mediterranean as derived from Coastal Zone Color Scanner observations. Journal of Geophysical Research, 100: 193-209.

Bernasconi, S. \& Pika-Biolzi, M. 2000. A stable isotope study of multiple species of planktonic foraminifera across sapropels of the Tyrrhenian Sea, ODP Site 974. Palaeogeography, Palaeoclimatology, Palaeoecology, 158: 281-292.

Bethoux, J.P., Gentili, B., Morin, P., Nicolas, E., Pierre, C. \& Riuz-Pino, D. 1999. The Mediterranean Sea: a miniature ocean for climatic and environmental studies and a key for the climatic functioning of the North Atlantic. Progress in Oceanography, 44: $131-146$.

Bé, A.W.H. \& Tolderlund, D.S. 1971. Distribution and ecology of living planktonic Foraminifer in surface waters of the Atlantic and Indian oceans. In: Funnel, B.M. \& Riedel, W.R. (Eds), The Micropaleontology of the oceans. Cambridge University Press, Cambridge, 105-149.

Béranger, K., Mortier, L. \& Crépon, M. 2005. Seasonal variability of water transport through the Straits of Gibraltar, Sicily and Corsica, derived from a high-resolution model of the Mediterranean circulation. Progress in Oceanography, 66: 341-364.

Béthoux, J.P. 1993. Mediterranean sapropel formation, dynamic and climatic viewpoints. Oceanologica Acta, 16: 127-133.

Calvert, S.E. \& Pedersen, T. 1992. Organic carbon accumulation and preservation in marine sediments: how important is anoxia? In: Whelan, J. \& Farrington, J.W. (Eds), Productivity, Accumulation and Preservation of Organic Matter in Recent and Ancient Sediments. Columbia University Press, Columbia, 231-263.

Capotondi, L. \& Vigliotti, L. 1999. Magnetic and microfaunistical characterization of late Quaternary sediments in the Western Mediterranean (ODP Leg 161). Inference on sapropel formation and paleoceanographic evolution. In: Zahn, R., Comas, M.C. \& Klaus, A. (Eds), Proceedings of the Ocean Drilling Program, Scientific Results, 161: $505-518$.
Capotondi, L., Morigi, C., Turi, B. \& Brilli, M. 2000. Biological and oxygen isotope records in Late Quaternary sediments from the Eastern Mediterranean Sea. Istituto Lombardo Accademia di Scienze e Lettere, Milano, 134: 169-183.

Capotondi, L., Principato, M.S., Morigi, C., et al. 2006. Foraminiferal variations and stratigraphic implications to the deposition of sapropel $\mathrm{S} 5$ in the eastern Mediterranean. Palaeogeography, Palaeoclimatology, Palaeoecology, 235: 48-65.

Castradori, D. 1993. Calcareous nannofossil biostratigraphy and biochronology in eastern Mediterranean deep-sea cores. Rivista Italiana di Paleontologia e Stratigrafia, 99: 107-126.

Ciaranfi, N., D’Alessandro, A., Girone, G., Maiorano, P., Marino, M., Soldani, D. \& Stefanelli, S. 2001. Pleistocene sections in the Montalbano Jonico area and the potential GSSP for Early-Middle Pleistocene in the Lucania Basin (Southern Italy). Memorie di Scienze Geologiche, 53: 67-83.

Cita, M.B. \& Grignani, D. 1982. Nature and origin of Late Neogene Mediterranean sapropels. In: Schlanger, S.S. \& Cita, M.B. (Eds), Nature and origin of Cretaceous carbon-rich facies. Academic Press, London, 165-196.

Cita, M.B. \& Podenzani, M. 1980. Destructive effects of oxygen starvation and ash falls on benthic life: a pilot study. Quaternary Research, 13 (2): 230-241.

Cita, M.B. \& Zocchi, M. 1978. Distribution patterns of benthic foraminifera on the floor of the Mediterranean Sea. Oceanologica Acta, 1: 445-462.

Comas, M.C., Zahn, R., Klaus, A., et al. 1996. Proceedings of the Ocean Drilling Program, Initial Reports, 161.

Corliss, B.H. 1985. Microhabitats of benthic foraminifera within deepsea sediments. Nature, 314: 435-438.

Corliss, B.H. \& Emerson, S. 1990. Distribution of Rose Bengal stained deep-sea benthic foraminifera from the Nova Scotian continental margin and Gulf of Maine. Deep-Sea Research, 37: $381-400$.

Cramp, A. \& O'Sullivan, G. 1999. Neogene sapropels in the Mediterranean: a review. Marine Geology, 153: 11-28.

de Kaenel, E., Siesser, W.G. \& Murat, A. 1999. Pleistocene calcareous nannofossil biostratigraphy and the Western Mediterranean sapropels, Sites 974 to 977 and 979. In: Zahn, R., Comas, M.C. \& 
Klaus, A. (Eds), Proceedings of the Ocean Drilling Program, Scientific Results, 161: 159-181.

De Rijk, S., Hayes, A. \& Rohling, E.J. 1999. Eastern Mediterranean Sapropel S1 interruption: an expression of the onset of climatic deterioration around 7kaB.P. Marine Geology, 153: 337-343.

De Stigter, H.C., Jorissen, F.J. \& Van der Zwaan, G.J. 1998. Bathymetric distribution and microhabitat partitioning of live (Rose Bengal stained) benthic foraminifera along a shelf to deep sea transect in the southern Adriatic Sea. Journal of Foraminifera Research, 28: 20-65.

Emeis, K.-C. \& and Leg 160 Shipboard Scientific Party 1996. Paleoceanography and sapropel introduction. In: Emeis, K.-C., Robertson, A.H.F., Richter, C., et al. (Eds), Proceedings of the Ocean Drilling Program, Initial Reports, 160: 21-28.

Emeis, K.-C., Sakamoto, T., Wehausen, R. \& Brumsack, H.-J. 2000. The sapropel record of the eastern Mediterranean Sea - results of Ocean Drilling Program Leg 160. Palaeogeography, Palaeoclimatology, Palaeoecology, 158: 371-395.

Fairbanks, R.G. \& Wiebe, P.H. 1980. Foraminifera and Chlorophyll maximum: vertical distribution, seasonal succession, and paleoceanographic significance. Science, 209: 1524-1526.

Gooday, A.J. 1994. The biology of deep-sea foraminifera: a review of some advances and their applications in paleoceanography. Palaios, 9: 14-31.

Hammer, Ø., Harper, D.A.T. \& Ryan, P.D. 2001. PAST: Paleontological Statistics Software Package for Education and Data Analysis. Palaeontologia Electronica, 4(1): 9pp. [Available on World Wide Web at http://palaeo-electronica.org/2001_1/past/issue1_01.htm.].

Hassold, N., Rea, D.K. \& Meyers, P.A. 2003. Grain size evidence for variations in delivery of terrigenous sediments to a Middle Pleistocene interrupted sapropel from ODP Site 969, Mediterranean Ridge. Palaeoceanography, Palaeoclimatology, Palaeoecology, 190: 211-219.

Hilgen, F.J. 1991. Astronomical calibration of Gauss to Matuyama sapropels in the Mediterranean and implication for the Geomagnetic Polarity Time Scale. Earth and Planetary Scientific Letters, 104: 226-244.

Howell, M.W., Thunell, R.C., Di Stefano, E., Sprovieri, R., Tappa, E.J. \& Sakamoto, T. 1998. Stable isotope chronology and paleoceanographic history of Sites 963 and 964, Eastern Mediterranean Sea. In: Robertson, A.H.F., Emeis, K.-C., Richter, C. \& Camerlenghi, A. (Eds), Proceedings of the Ocean Drilling Program, Scientific Results, 160: $67-80$.

Jorissen, F.J. 1999. Benthic foraminiferal successions across Late Quaternary Mediterranean sapropels. Marine Geology, 153: 91-101.

Jorissen, F.J., Barmawidjaja, D.M., Puskaric, S. \& van der Zwaan, G.J. 1992. Vertical distribution of benthic foraminifera in the northern Adriatic Sea: relation with the organic flux. Marine Micropaleontology, 19: 131-146.

Jorissen, F.J., de Stigter, H.C. \& Vidmark, J.V. 1995. A conceptual model explaining benthic foraminiferal microhabitats. Marine Micropaleontology, 26: 3-15.

Lascaratos, A., Roether, W., Nittis, K. \& Klein, B. 1999. Recent changes in deep water formation and spreading in the eastern Mediterranean Sea: a review. Progress in Oceanography, 44: 5-36.

Loubere, P. 1997. Benthic foraminiferal assemblage formation, organic carbon flux and oxygen concentrations on the outer continental shelf and slope. Journal of Foraminiferal Research, 27 (2): 93-100.

Lourens, L.J., Hilgen, F.J., Gudjonsson, L. \& Zachariasse, W.J. 1992. Late Pliocene to early Pleistocene astronomically forced sea surface productivity and temperature variations in the Mediterranean. Marine Micropaleontology, 19: 49-78.

Mackensen, A. \& Douglas, R.G. 1989. Down-core distribution of live and dead deep-water benthic foraminifera in box cores from the Weddell Sea and the California continental borderland. Deep-Sea Research, 36: 879-900.

Maiorano, P., Marino, M., Di Stefano, E. \& Ciaranfi, N. 2004. Calcareous nannofossil events in the Lower-Middle Pleistocene transition at Montalbano Jonico section (Southern Italy) and ODP Site 964 (Ionian Sea), and their calibration with oxygen isotope and sapropel stratigraphy. Rivista Italiana di Paleontologia e Stratigrafia, 110 (2): 547-557.

Meyers, P.A. \& Arnaboldi, M. 2005. Trans-Mediterranean comparison of geochemical paleoproductivity proxies in a mid-Pleistocene inter- rupted sapropel. Palaeogeography, Palaeoclimatology, Palaeoecology, 222: 313-328.

Meyers, P.A. \& Bernasconi, S. 2005. Carbon and nitrogen isotope excursions in mid-Pleistocene sapropels from the Tyrrhenian Basin: evidence for climate-induced increases in microbial production. Marine Geology, 220: 41-58.

Mullineaux, L.S. \& Lohmann, G.P. 1981. Late Quaternary stagnations and recirculation of the Eastern Mediterranean: changes in the deep water recorded by fossil benthic foraminifera. Journal of Foraminiferal Research, 11: 20-39.

Murat, A. 1999. Pliocene-Pleistocene occurrence of sapropels in the western Mediterranean Sea and their relation to eastern Mediterranean sapropel S1. In: Zahn, R., Comas, M.C. \& Klaus, A. (Eds), Proceedings of the Ocean Drilling Program, Scientific Results, 161: $519-527$.

Myers, P.G. \& Rohling, E.J. 2000. Modelling a 200-yr interruption of the Holocene sapropel S1. Quaternary Research, 53: 98-104.

Negri, A., Capotondi, L. \& Keller, J. 1999. Calcareous nannofossils, planktonic foraminifera and oxygen isotopes in the late Quaternary sapropels of the Ionian Sea. Marine Geology, 157: 89-103.

Nijenhuis, I.A., Becker, J. \& De Lange, G.J. 2001. Geochemistry of coeval marine sediments in Mediterranean ODP cores and a land section: implications for sapropel formation models. Palaeogeography, Palaeoclimatology, Palaeoecology, 165: 97-112.

Nolet, G.J. \& Corliss, B.H. 1990. Benthic foraminiferal evidence for reduced deep-water circulation during sapropel deposition in the eastern Mediterranean. Marine Geology, 94: 109-130.

Oggioni, E. \& Zandini, L. 1987. Response of benthic foraminifera to stagnant episodes - a quantitative study of core Ban 81-23, eastern Mediterranean. Marine Geology, 75: 241-261.

Parisi, E. 1981. Distribuzione dei foraminiferi bentonici nelle zone batiali del Tirreno e del Canale di Sicilia. Rivista Italiana di Paleontologia, 87: 293-328.

Parisi, E. \& Cita, M.B. 1982. Late Quaternary paleoceanographic changes recorded by deep-sea benthos in the western Mediterranean ridge. Geografia Fisica e Dinamica del Quaternario, 5: 102-114.

Pickard, G.L. \& Emery, W.J. 1990. Descriptive Physical Oceanography. An Introduction. Pergamon Press, Oxford, 158-165.

Pujol, C. \& Vergnaud-Grazzini, C. 1995. Distribution patterns of live planktic foraminifers as related to regional hydrography and productive systems of the Mediterranean Sea. Marine Micropaleontology, 25: $187-217$.

Reiss, Z., Halicz, E. \& Luz, B. 1999. Late Holocene foraminifera from the SE Levantine Basin, Isr. Journal of Earth Science, 48: 1-17.

Rohling, E.J. 1991. Shoaling of the eastern Mediterranean pycnocline due to reduction of excess evaporation: Implications for sapropel formation. Paleoceanography, 6 (6): 747-753.

Rohling, E.J. \& Gieskes, W.C. 1989. Late Quaternary changes in Mediterranean intermediate water density and formation rate. Paleoceanography, 4: 531-545.

Rohling, E.J. \& Hilgen, F.J. 1991. The eastern Mediterranean climate at times of sapropel formation: a review. Geologie en Mijnbouw, 70: 253-264.

Rohling, E.J., De Stigter, H.C., Vergnaud-Grazzini, C. \& Zaalberg, R. 1993. Temporary repopulation by low-oxygen tolerant benthic foraminifera within an upper Pliocene sapropel: evidence for the role of oxygen depletion in the formation of sapropels. Marine Micropaleontology, 22: 207-219.

Rohling, E.J., Jorissen, F.J. \& De Stigter, H.C. 1997. 200 Year interruption of Holocene sapropel formation in the Adriatic Sea. Journal of Micropaleontology, 16: 97-108.

Ross, C.R. \& Kennett, J.P. 1983/84. Late Quaternary paleoceanography as recorded by benthonic foraminifera in Strait of Sicily sediment sequences. Marine Micropaleontology, 8: 315-336.

Rossignol-Strick, M. 1983. African monsoons, an immediate climate response to orbital insolation. Nature, 304: 46-49.

Rossignol-Strick, M. 1985. Mediterranean Quaternary sapropels, an immediate response of the African monsoon to variation of insolation. Palaeogeography, Palaeoclimatology, Palaeoecology, 49: 237-263.

Rossignol-Strick, M., Nestero, W., Olive, P. \& Vergnaud-Grazzini, C. 1982. Mediterranean stagnation and sapropel formation. Nature, 295: $105-110$. 
Sancetta, C. 1994. Mediterranean sapropels: seasonal stratification yields high production and carbon flux. Paleoceanography, 9: 195-196.

Sancetta, C. 1999. The mystery of the sapropels. Nature, 398: 27-28.

Sautter, L.R. \& Thunell, R.C. 1991. Seasonal variability in the $\delta^{18} \mathrm{O}$ and $\delta^{13} \mathrm{C}$ of planktonic foraminifera from an upwelling environment: sediment trap results from the San Pedro basin, southern California Bight. Paleoceanography, 6: 307-334.

Schiebel, R. \& Hemleben, C. 2000. Interannual variability of planktic foraminifera populations and test flux in the eastern North Atlantic Ocean (JGOFS). Deep-Sea Research, 47: 1809-1852.

Schmiedl, G., Hemleben, C., Keller, J. \& Segl, M. 1998. Impact of climatic changes on the benthic foraminiferal fauna in the Ionian sea during the last 330,000 years. Paleoeceanography, 13: 447-458.

Schmiedl, G., de Bovée, F., Buscail, R., Charrière, B., Hemleben, Ch., Medernach, L. \& Picon, P. 2000. Trophic control of benthic foraminiferal abundance and microhabitat in the bathyal Gulf of Lions, western Mediterranean Sea. Marine Micropaleontology, 40: $167-188$.

Schmiedl, G., Mitschele, A., Beck, S., et al. 2003. Benthic foraminiferal record of ecosystem variability in the eastern Mediterranean Sea during times of sapropel S5 and S6 deposition. Palaeogeography, Palaeoclimatology, Palaeoecology, 190: 139-164.

Sen Gupta, B.K. \& Machain-Castillo, M.L. 1993. Benthic foraminifera in oxygen poor habitats. Marine Micropaleontology, 20: 183-201.

Send, U., Font, J., Krahmann, G., Millot, C., Rhein, M. \& Tintoré, J. 1999. Recent advances in observing the physical oceanography of the western Mediterranean Sea. Progress in Oceanography, 44: 37-64.

Sgarrella, F. \& Moncharmont Zei, M. 1993. Benthic foraminifera of the Gulf of Naples (Italy): systematic and autoecology. Bollettino della Società Paleontologica Italiana, 32 (2): 145-264.

Stefanelli, S. 2004. Cyclic changes in oxygenation based on foraminiferal microhabitats: Early-Middle Pleistocene, Lucania Basin (southern Italy). Journal of Micropaleontology, 23: 1-15.
Stefanelli, S., Capotondi, L. \& Ciaranfi, N. 2005. Foraminiferal record and environmental changes during the deposition of the earlymiddle Pleistocene sapropels in southern Italy. Palaeogeography, Palaeoclimatology, Palaeoecology, 216: 27-52.

Tang, C.M. \& Stott, L.D. 1993. Seasonal salinity changes during Mediterranean sapropel deposition 9000 years B.P.: evidence from isotopic analyses of individual planktonic foraminifera. Paleoceanography, 8: 473-493.

Thunell, R.C. 1978. Distribution of recent plantonic foraminifera in surface sediments of the Mediterranean Sea. Marine Micropaleontology, 3: 147-173.

Thunell, R.C. \& Reynolds, L.A. 1984. Sedimentation of planktonic foraminifera: Seasonal exchange in species flux in Panama Basin. Micropaleontology, 30 (3): 243-262.

Thunell, R.C. \& Williams, D.F. 1989. Glacial-Holocene salinity changes in the Medirerranean Sea: Hydrographic and depositional effects. Nature, 338: 493-496.

Thunell, R.C., Williams, D.F. \& Cita, M.B. 1983. Glacial anoxia in the Eastern Mediterranean. Journal of Foraminiferal Research, 13 (4): 283-290.

van der Zwaan, G.J. 1983. Quantitative analyses and the reconstruction of benthic foraminiferal communities. Utrecht Micropaleontological Bullettins, 30: 49-69.

Vismara-Schilling, A. 1984. Holocene stagnation event in the eastern Mediterranean. Evidence from deep-sea benthic foraminifera in the Calabrian and western Mediterranean Ridges. Benthos'83: 2nd International Symposium on Benthic Foraminifera. Elf Aquitaine, Pau, France, 585-596.

von Grafenstein, R., Zamn, R., Tiedemann, R. \& Murat, A. 1999. Planktonic d180 records at Sites 976 and 977, Alboran sea: stratigraphy, forcing and paleoceanographic implications. In: Zahn, R., Comas, M.C. \& Klaus, A. (Eds), Proceedings of the Ocean Drilling Program, Scientific Results, 161: 469-479.

Wust, G. 1961. On the vertical circulation of the Mediterranean Sea. Journal of Geophysical Research, 66 (10): 3261-3271. 